Andrews University

Digital Commons @ Andrews University

1975

\title{
Perception of Values Relating to Character Development: A Study of College Students' Views on a Seventh-day Adventist Campus
}

Gertrude Elizabeth Jordan

Andrews University

Follow this and additional works at: https://digitalcommons.andrews.edu/theses

Part of the Educational Psychology Commons, and the Higher Education Commons

\section{Recommended Citation}

Jordan, Gertrude Elizabeth, "Perception of Values Relating to Character Development: A Study of College Students' Views on a Seventh-day Adventist Campus" (1975). Master's Theses. 164.

https://dx.doi.org/10.32597/theses/164

https://digitalcommons.andrews.edu/theses/164

This Thesis is brought to you for free and open access by the Graduate Research at Digital Commons @ Andrews University. It has been accepted for inclusion in Master's Theses by an authorized administrator of Digital Commons@ Andrews University. For more information, please contact repository@andrews.edu. 


\title{
ABSTRACT OF GRADUATE STUDENT RESEARCH
}

Thesis

\author{
Andrews University
}

Department of Education

Title: PERCEPTION OF VALUES RELATING TO CHARACTER DEVELOPMENT: A STUDY OF COLLEGE STUDENTS' VIEWS ON A SEVENTH-DAY ADVENTIST CAMPUS

Name of Researcher: Gertrude E. Jordan

Name and title of faculty advisers: Ruth R. Murdoch, Ed.D., Chairman Wilfred G. A. Futcher, Ph.D. John B. Youngberg, Ed.D.

Date completed: July 1975

\section{Problem}

The most important concern of Seventh-day Adventists is the proper and fullest development of character. This study investigates perception patterns on character values and factors influencing positive character development held by subjects on a church supported university campus (Andrews University).

\section{Method}

The self-administered questionnaire, developed by Kreps (1970) to examine the attitudes held by college students concerning values that are important in promoting positive character development in individuals, was modified in part to conform to background 
characteristics of Andrews University students. The socio-economic class of each subject was determined by the McGuire-White Social Class Index (1955). A percentage and frequency count and the chisquare test were employed to analyze the data. Randomized selected subjects were proportionally stratified by $\operatorname{sex}(N=185)$ 。

\section{Results}

Subjects selected Spiritual Development, Honesty and Integrity, Seeing Each Person as Having Dignity and Worth, SelfDiscipline, and Moral Courage as the five most important values involved in character development. Self-Reliance, Determination, and Intellectual Inquisitiveness were the values selected as ones parents most often succeed in helping children learn. Spiritual Development, Self-Discipline, and Seeing Each Person as Having Digntty and Worth were the values selected as ones parents most often fail to help children learn. Subjects selected the Mother (parent) and the Family (social institution) as having the greatest influence on the child's character development. Model and Examples was selected most often as the most effective manner to learn values. Reward and Punishment was selected most often as the method parents use to teach character values. A11 of the non-directional nu11 hypotheses were supported.

\section{Conclusions}

From the data of this study and the research reviewed, it would appear.that SDA philosophy influenced the perception rankings. The findings suggest that sex exerts an influence on the values held. Results of this study, because of the randomizing selection of subjects (as opposed to the biased method used by Kreps in her study) are more precise (and do not agree with Kreps) in this regard.

It is recommended that this investigation be duplicated with (a) a national sample of high school and college students, (b) a cross-culture interfaith sample of SDA students, and (c) an interfaith sample of college students. 
Andrews University

School of Graduate Studies

PERCEPTION OF VALUES RELATING TO CHARACTER DEVELOPMENT:

A STUDY OF COLLEGE STUDENTS' VIEWS ON A SEVENTH-DAY ADVENTIST CAMPUS

\author{
A Thesis \\ Presented in Partial Fulfillment \\ of the Requirements for the Degree \\ Master of Arts
}

by

Gertrude EI.izabeth Jordan

July 1975

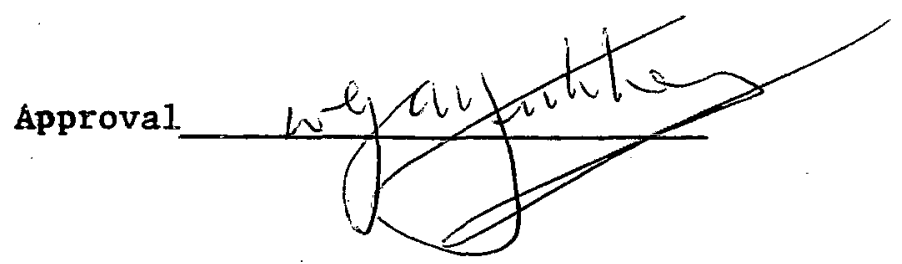


TABLE OF CONTENTS

Page

LIST OF TABLES ....................... . iv

Chapter

I. INTRODUCTION . . . . . . . . . . . . . . 1

Statement of the Problem ............ 3

Purpose of the Study .............. 4

Definition of Terms .............. 6

Development of the Hypotheses .......... 7

Organization of the Study........... 12

II. REVIEW OF THE LITERATURE . . . . . . . . . . . 14

Historical View on Aspects of Character

Development ............. . . 14

Interpretations of Character ........... 15

Age at Which Moral Character is Formed . . . . . 18

Development of Moral Ideology and Judgment . . . . 19

Value Definitions . . . . . . . . . . . 23

Acquiring Values ............... 24

III. THE RESEARCH DESIGN ................ 27

Population and Sample ............. 27

Limitations . . . . . . . . . . . . 27

Instruments . . . . . . . . . . . . . . . 28

Procedure ................. . 30

Analysis of Data ............... 30

IV. PRESENTATION AND ANALYSIS OF DATA . . . . . . . 32

Introduction . . . . . . . . . . . 32

Description of the Subjects .......... 32

Analysis of Perceptions . . . . . . . . . . . 36

Data Pertaining to the Hypotheses . . . . . . 42

Examination of Hypotheses ............ 42 
V. DISCUSSION OF FINDINGS ............ 60

Introduction ............... 60

Perceptions of the Most Important Values for

Parents to Assist Children in Learning in

Order to Promote Positive Character

Development ................ 60

Perceptions of Values Which Parents are Most

Successful in Helping Children Learn . . . . . 64

Perceptions of Values Which Parents Most

Often Fail to Help Children Learn . . . . . 72

Perceptions of Source of Greater Parental

Influence of the Character Development

of Children ................ 76

Perceptions of Source of Greatest Community

Influence on Character Development . . . . . . 77

Perceptions of the Most Effective Manner

in Which Values Involved in Character

Development are Learned . . . . . . . . . 79

Perceptions of the Manner Parents Most Often

Use to Help Children Learn Values Involved

in Character Development . . . . . . . . 81

VI. SUMMARY, RECOMMENDATIONS, AND CONCLUSIONS . . . . . 83

Summary .................. 83

Recommendations ............. 85

Conclusions ................. 86

BIBLIOGRAPHY .................... 88

APPENDICES

1. Form Letter for Community Students . . . . . . . 96

2. Form Letter for Dormitory Students . . . . . . . 97

3. Sample of Questionnaire ............ 98

4. McGuire-White Social Class Index . . . . . . . 104 


\section{LIST OF TABLES}

Table

Page

1. Characteristics of the Subjects ......... .

2. Perceptions Concerning the Most Important

Values for Parents to Assist Their Children

in Learning in Order to Promote Positiye

Character Development . . . . . . . . . .

3. Perceptions of Values Parents are Most Successful

in Helping Their Children Learn ... . . . . . .

4. Perceptions of the Values Parents Most Often

Fail to Help Children Learn ............ 40

5. Perceptions of the Source of Greater Parental

Influence on Character Development ........

6. Perceptions of Greatest Community Influence on Character Development . . . . . . . . .

7. Perceptions of the Most Effective Manner in which Values Involved in Character Development are Learned . . . . . . . . . . . . . .

8. Perceptions of the Manner which Parents Most often Use to Help Children Learn Values Involved in Character Development ......... 43

9. Greater Parental Influence and Sex ... . . . . 44

10. Greater Parental Influence and Age ........ 44

11. Greater Parental Influence and Race ..... . . 44

12. Greater Parental Influence and Mother Employment ............. 45

13. Greater Parental Influence and Residence ...... 45

14. Greater Parental Influence and Parents Marital Status .............. 
LIST OF TABLES (Continued)

Table

Page

15. Greater Parental Influence and Socio-

Economic Status . . . . . . . . . . . .

16. Greater Parental Influence and Relationship with Parents

17. Greatest Community Influence and Sex ....... 47

18. Greatest Community Influence and Age . . . . . 47

19. Greatest Community Influence and Race . . . . . 48

20. Greatest Community Influence and Mother Employment • 48

21. Greatest Community Influence and Residence . . . 49

22. Greatest Community Influence and Parents Marital Status ...............

23. Greatest Community Influence and SocioEconomic Status . . . . . . . . . . . .

24. Greatest Community Influence and Relationship with Parents

25. Most Éffective Manner to Learn

Values and Sex ................

26. Most Effective Manner to Learn

Values and Age .................

27. Most Effective Manner to Learn

Values and Race ..................

28. Most Effective Manner to Learn

Values and Residence . . . . . . . . . .

29. Most Effective Manner to Learn Values and Family Relations Course ...........

30. Most Effective Manner to Learn Values and Type of Discipline .............

31. Most Effective Manner to Learn Values and Relationship with Parents ......... 


\section{LIST OF TABLES (Continued)}

Table

Page

32. Manner Most Often Used to Teach

values and Sex ............ 54

33. Manner Most Often Used to Teach

Values and Age .............. 55

34. Manner Most Often Used to Teach

Values and Race.............. 55

35. Manner Most Often Used to Teach

Values and Mother Employment .......... 56

36. Manner Most often Used to Teach

Values and Residence ............ 56

37. Manner Most Often Used to Teach

Values and Socio-Economic Status ....... 57

38. Manner Most Often Used to Teach

Values and Type of Discipline . . . . . . 57

39. Manner Most Often Used to Teach

Values and Relationship with Parents ...... 58

40. McGuire-White Social Class Index--Occupations . . 106 
CHAPTER I

\section{INTRODUCTION}

The most important concern of Seventh-day Adventists (SDA) is the proper and fullest development of character. It is the church ${ }^{2} s$ position that "Character building is the most important work ever entrusted to human beings (White, 1903a, p. 225)." Likewise, it is the church's belief that "A character formed according to the divine likeness is the only treasure that we can take from this world to the next. - . How important, then, is the development of character in this life (White, 1954, pp. 161, 163)." Christian ethics must be directed toward a developing and strengthening of the character. "Success here implies not only a mature discretion and insight into the basal principles of morality, but also a thorough understanding of one's own temperament and of mankind and the world (Koest1in, 1958, p. 11)."

Psychologically, Peck and Havighurst (1960, p. v) have suggested that no aspect of life is more essential to human happiness and survival than is an objective knowledge and understanding of the development of man's character. Bradley and Earp (1966) state that

The cultivation of a child's mind (self-government) to the habit of obeying the dictates of honor and duty as enforced by action, will-power, and integrity, is imperative if one is to believe in, advocate, and strive for strength of character ( $p .55$ ). 
Havighurst and Taba (1949) wrote that "Character is ranked by most people as of first importance in the child's education (p. 3)." These forceful statements point to the importance of character development.

The concepts of character and character development in philosophical, psychological, sociological, and religious study are receiving increasing attention in recent periods. The works of Hartshorne and May (1928-1930), Piaget (1932), Peck and Havighurst (1960), and Kohlberg (1964) are being studied with renewed interest and fresh insight. Although there is much discussion on character development, there is relatively little scientific research dealing with the inner forces that shape and determine man's character (Peck \& Havighurst, 1960, p. v).

A need exists for much more clarification concerning the components of character. Stinnett and Kreps (1973) observed that the basic challenge for future research in the area of character development seems to be that of identifying the values considered most important in promoting positive character development and fulfilling human living ( $p .53$ ).

When such values are identified, defined, clarified, and organized, educators can more effectively assist the individual in positive character development and empirical results can be more accurately interpreted.

Another problem is that of distinguishing "character" from "personality." Some psychologists use the two terms synonymously, except that character has for them an evaluative connotation. There is overlapping and interdependence between the two concepts, but personality typically refers to the totality 
of human feelings and behavior with no particularly specialized interest in values, volition, or ethical conduct (Jones, 1960, p. 184).

Conscience, ethical conduct, values, and volition are the very problems which are central to character.

A third problem exists in the changing nature of the American family. Martin (1971), referring to Bronfenbrenner (1967), stated that "the family is playing a much less significant role in determining core values for their children because of the dissolution of a close neighborhood bond that kept the value lid from being uncorked (p. 4)." Parents do not know their own values (Kohlberg, 1964, p. 423), and therefore, in character development, may not present cleax models for the child to assimilate. Coupled with this is the influence of the mass media in shaping standards. "Movies, radio and television and all forms of mass communication are constantly presenting value models which either strengthen or dilute the teaching of the family... (Parrilla, 1971, p. 5 referring to Horn, 1968, p. 82)..8

\section{Statement of the Problem}

In view of the recognized importance of character development and the increasing interest in factors which shape character, it seemed worthwhile to study some of these factors. The thesis of Carroll Ann Kreps (1970), "College Students' Perceptions of Values Involved in Character Development," offered a possible model to follow. Kreps (1970) suggested that "There is a need to increase the understanding of the processes that intervene between the parent's child-rearing patterns and the child's eventual moral or character development (p. 3)." She wrote: 
Though much has been written about character, very little research has been conducted concerning character development, especia11y during recent years. As Sullivan, McCullough and Stager (1970) have indicated, there is a need for much more research in this area to confirm existing theories of character development (p. 3).

Kreps (1970) states that

There is a particular need for research concerning the attitudes of college students toward character development since they have so recently gone through the process and will have recent memories of the character qualities that were emphasized during childhood (p. 3).

She developed the Positive Character Values List to examine the perceptions of volunteer college students at Oklahoma State University concerning

(a) the most important values involved in positive character development, (b) those values which parents most and least effectively help their children learn, and (c) the most effective manner in which such values are learned (Stinnett. and Kreps, 1972, p. 53).

The results of Kreps (1970) study, conducted on a public university campus, posed two questions: (a) Would a duplicated study yield similar results when conducted on a church supported university campus? (b) Would a stratified by sex sample reveal differences in perception patterns held by subjects? This study was designed to find answers to these questions. The problem related to this paper may therefore be summarized as the need to increase knowledge concerning perception rankings of the values involved in positive character development, and the manner in which such values are learned.

\section{Purpose of the Study}

The general purpose of this study was to replicate Kreps" (1970) study with the following differences: (a) The study was to 
be conducted on a church related university campus. (b) Subjects for the study were randomly selected instead of using class volunteers. The specific purposes of this study were:

1. To determine the perceptions of college students on a SDA campus concerning: (a) the five values believed to be most important for parents to assist their children in learning in order to promote positive character development, (b) the three values which parents are most successful in helping their children learn, (c) the three values which parents most often fail to help their children learn, (d) the source of greater parental influence on the character development of children, (e) the source of greatest community influence on the character development of children, (f) the most effective manner in which the values involved in character development are learned, and $(\mathrm{g})$ the manner which parents most often help children learn values involved in character development

2. To determine if perceptions concerning the source of greater parental influence on the character development of children are significantly related to: (a) sex, (b) age, (c) race, (d) employment status of mother, (e) residence, (f) marital status of parents, (g) socio-economic status, and $(h)$ happiness of childhood relationships with parents.

3. To determine if perceptions concerning the source of greatest community influence on the character development of children are significantly related to: (a) sec, (b) age, (c) race, (d) employment status of mother, (e) residence, (f) marital status of parents, (g) socio-economic status, and (h) happiness of childhood relationships with parents. 
4. To determine if perceptions concerning the most effective manner in which the values involved in character development are learned are significantly related to: (a) sex, (b) age, (c) race, (d) residence, (e) exposure to a family relations course, (f) prevailing type of discipline in family of orientation, and ( $g$ ) happiness of childhood relationship with parents.

5. To determine if perceptions concerning the mannex in which parents most often help children learn values involved in character development are significantly related to: (a) sex, (b) age, (c) race, (d) employment status of mother, (e) residence, (f) socio-economic status, (g) prevailing type of discipline in family of orientation and ( $h$ ) happiness of childhood relationship with parents.

\section{Definition of Terms}

Andrews University. This is an institution operated jointly by the General Conference of SDA and the Lake Union Conference of SDA. It was the first university to be organized by the SDA Church. The University is comprised of four schools: The College, the School of Technology, the School of Graduate Studies, and the SDA Theological Seminary. The University is accredited by the North Central Assocition of Colleges and Secondary Schools and the National Council for the Accreditation of Teacher Education. It is recognized as a teacher training institution by the Michigan State Board of Education.

Character. For the purpose of this study, character is defined as "an individual's set of values which serve to guide his behavior (Kreps, 1970, p. 4)." 
Character Development. Character development is the growth of moral qualities, ethical standards, conscience, thoughts and conduct, values, volition, and the like.

Perception. "Perception is a single, unified awareness derived from sensory processes while a stimulus is present (Random House, 1966, p. 1069)."

PCV List. The Positive Character Values List. This is a list of values most often considered to promote positive character development and fulfill human living.

SDA. Seventh-day Adventist. The official name of a specific conservative Christian denomination.

Values. Stinnett and Kreps (1972) definition here refers "to personal qualities considered by the individual as desirable and worthy (p. 53)."

\section{Development of the Hypotheses}

The following non-directional null hypotheses are projected for testing:

1a. There is no significant difference in perceptions concerning the source of greater parental influence on the character development of children when respondents are classified according to sex.

1b. There is no significant difference in perceptions concerning the source of greater parental influence on the character development of children when respondents are classified according to age. 
1c. There is no significant difference in perceptions concerning the source of greater parental influence on the character development of children when respondents are classified according to race.

1d. There is no significant difference in perceptions concerning the source of greater parental influence on the character development of children when respondents are classified according to employment status of mother.

1e. There is no significant difference in perceptions concerning the source of greater parental influence on the character development of children when respondents are classified according to residence.

1f. There is no significant difference in perceptions concerning the source of greater parental influence on the character development of children when respondents are classified according to marital status of parents.

1g. There is no significant difference in perceptions concerning the source of greater parental influence on the character development of children when respondents are classified according to socio-economic class.

1h. There is no significant difference in perceptions concerning the source of greater parental influence on the character development of children when respondents are classified according to happiness of childhood relationship with parents.

2a. There is no significant difference in perceptions concerning the source of greatest community influence on the character 
development of children when respondents are classified according to sex.

2b. There is no significant difference in perceptions concerning the source of greatest community influence on the character development of children when respondents are classified according to age.

2c. There is no significant difference in perceptions concerning the source of greatest community influence on the character development of children when respondents are classified according to race.

2d. There is no significant difference in perceptions concerning the source of greatest community influence on the character development of children when respondents are classified according to employment status of mother.

2e. There is no significant difference in perceptions concerning the source of greatest community influence on the character development of children when respondents are classified according to residence.

2f. There is no significant difference in perceptions concerning the source of greatest community influence on the character development of children when respondents are classified according to marital status of parents.

2g. There is no significant difference in perceptions concerning the source of greatest community influence on the character development of children when respondents are classified according to socioeconomic class. 
2h. There is no significant difference in perceptions concerning the source of greatest community influence on the character development of children when respondents are classified according to happiness of childhood relationship with parents.

3a. There is no significant difference in perceptions concerning the most effective manner in which the values involved in character development are learned when respondents are classified according to sex.

3b. There is no significant difference in perceptions concerning the most effective manner in which the values involved in character development are learned when respondents are classified according to age.

3c. There is no significant difference in perceptions con-cerning the most effective manner in which the values involved in character development are learned when respondents are classified according to race.

3d. There is no significant difference in perceptions concerning the most effective manner in which the values involved in character development are learned when respondents are classified according to residence.

3e. There is no significant difference in perceptions concerning the most effective manner in which the values involved in. character development are learned when respondents are classified according to exposure to a family relations course.

3f. There is no significant difference in perceptions concerning the most effective manner in which the values involved in 
character development are learned when respondents are classified according to prevailing type of discipline in family of orientation. $3 \mathrm{~g}$. There is no significant difference in perceptions concerning the most effective manner in which the values involved in character development are learned when respondents are classified according to happiness of childhood relationship with parents.

4a. There is no significant difference in perceptions concerning the manner in which parents most often help children learn values involved in character development when respondents are classified according to sex.

4b. There is no significant difference in perceptions concerning the manner in which parents most often help children learn values involved in character development when respondents are classified according to age.

4c. There is no significant difference in perceptions concerning the manner in which parents most often help children learn values involved in character development when respondents are classified according to race.

4d. There is no significant difference in perceptions concerning the manner in which parents most often help children learn values involved in character development when respondents are classified according to employment status of mother.

4e. There is no significant difference in perceptions concerning the manner in which parents most often help children learn values involved in character development when respondents are classified according to residence. 
4f. There is no significant difference in perceptions concerning the manner in which parents most often help children learn values involved in character development when respondents are classified according to socio-economic status.

4g. There is no significant difference in perceptions concerning the manner in which parents most often help children learn values involved in character development when respondents are classi-fied according to prevailing type of discipline in family of orientation.

4h. There is no significant difference in perceptions concerning the manner in which parents most often help children learn values involved in character development when respondents are classified according to happiness of childhood relationship with parents.

\section{Organization of the Study}

Chapter 1 deals with the basic rationale for the study. The problem and purpose of the study is presented. The hypotheses projected for testing are stated, together with the organizational outline.

Chapter II, the second chapter, deals with the research that has been done in the field of character development. Within this section, studies on the historical background on character development, interpretations of character, age when moral character is formed, theories of character development, value definitions and how values are acquired are reviewed.

Chapter III deals with the research design used. This includes information on the population and subjects, limitations of the study, instruments used in evaluation, the procedures utilized, and questionnaire data to be analyzed. 
Chapter IV presents the summarization and analysis of data. The data pertaining to the hypotheses is presented. The hypotheses are examined.

Chapter $\mathrm{V}$ focuses on possible reasons for the selected perception choices listed in Chapter IV. Respondent's choice selections are compared against responses in the Kreps (1970) study. Chapter VI, the final aspect of the study, is a summary of the major findings, recommendations for future investigations, and final conclusions drawn. 
CHAPTER II

REVIEW OF THE LITERATURE

The review of the literature will present (a) a historical view on aspects of character development, (b) interpretations of character, (c) age at which moral character is formed, (d) development of moral ideology and judgment, (e) value definitions, and (f) acquiring values.

\section{Historical View on Aspects of Character Development}

"Character" is a term derived from the Greek xapaxtńp, meaning engraving. Originally, the term meant an engraver or one who mints coins. It also referred to the brand used for the marking or the engraving as well as the pattern formed from the brand itself (Rothenberg, 1973, p. 291)。

Immanue1 Kant first invested the word "character" with an ethical quality. He distinguished between a physical and moral character by stating that "Man's physical character. . . represents merely what nature has made of him; his moral character is what he makes of himself (Kant quoted by Eucken, 1913, p. 364)." This ethical quality as well as stamping or patterning quality of character is seen in many definitions of moral character today (Bradley \& Earp, 1966, p. 55; Jones, 1960, p. 184; Lapsley, 1967, p. 51). 
White, a SDA writer, defines Christian character as "moral excellence and fine mental qualities. . (1890, p. 223)." Numerous statements are found in her writings on the ethical quality and the patterning quality of character: (1900, pp. 339, 340; 1930, p。144; 1948d, pp. 656, 657; 1954, p. 161, 164, 199, 202, 203; 1956, p。93). Kohlberg (1964, p. 383) points out that character's moral qualities have, for many generations been considered to be the key to understanding social relationships and development. He refers to the social sciences being termed "the moral sciences" and McDougall's (1908) statement that "the fundamental problem of social psychology is the moralization of the individual by the society (Kohlberg, p. 383)."

\section{Interpretations of Character}

Kohlberg (1964, pp. 387-392) provides a useful delineation of character interpretations: character as superego strength, character as good habits, and character as ego strength.

\section{Character as Superego Strength}

Peck and Havighurst (1960) define superego strength as the "degree to which behavior is directed by a set of internalized moral principles--a conscience (p. 21)." Other writers (d'Arcy, 1967, pp. 66-68; Dupre \& Williams, 1967, pp. 196-204; Golddiamond, 1968, p. 32; Jersild, 1968, p. 511; Mouly, 1968, p. 478; etc.) define the conscience in similar manner. Kohlberg (1964, pp. 387, 388), reviewing the works of Havighurst and Taba (1949), Hendry (1960), and Hartshorne and May (1928-1930), concluded that research findings on 
this interpretation are inconclusive; conformity to a moral rule does not bear a significant correlation to the strength of stated belief in that rule.

White wrote several statements $(1885,1894 \mathrm{a}, 1894 \mathrm{~b}, 1898 \mathrm{~b}$, 1948b, pp.90, 91) that allude to and support Kohlberg's conclusions. The most striking statement was:

When the truth is held as truth only by the conscience, when the heart is not stimulated and made receptive, the truth only agitates the mind. But when the truth is received as truth by the heart, it has passed through the conscience, and captivated the soul by its pure principles. It is placed in the heart by the Holy Spirit, who molds its beauty to the mind that its transforming power may be seen in the character (1897a).

White, as well as other religious writers (d'Arcy, 1967, pp. 66-68; Dupre \& Williams, 1967, pp. 196, 197) view conscience as a component of character and not character itself.

\section{Character as Good Habits}

Moral character is here interpreted as a set of general "good habits" produced by training, example, punishment, and reward (Kohlberg, 1964, p. 388). Kohlberg (1964, p. 388), reviewing the study of Hartshorne and May (1928-1930), wrote that they found a relationship between behavior tests of honesty or service and association with character building agencies such as church, Sunday school, or Boy Scouts. Kohlberg (1964, pp. 388, 389) further points out that research results on training, obedience, punishment and reward (Bandura \& Walters, 1959; Grinder, 1962, 1963; Rau, 1965; etc.) have generally failed to support the interpretation of character developing through good habits. He states (1966) "This conception 
of (teaching) character education appears to be just as ineffective in the home as it is in the school (p. 14)."

Several writers (Mouly, 1968; White, 1930, p. 379, 1943, p. 109; Wolfson, 1967, p. 47) stress the need of developing mental skills and habits of mind and understanding as opposed to indoctrinational aspects of training. Recent 1iterature (Bradley \& Earp, 1966, p. 56; Junell, 1969, p. 450; Mouly, 1968, pp. 455, 475; Pressey, 1957, p. 668; White, 1948d, p. 286) points out the importance of example and the need of quality relationships to good moral development. Some writers (Hurlock, 1967, pp. 447-449; Mussen \& Martin, 1960, p. 197; Peck \& Havighurst, 1960, pp. 123, 180, 181; White, 1898c, 1943, pp. 111, 112, 1948a, p. 388, etc.) view a democratic contro1 (in discipline, reward, and punishment) as a necessary factor in securing the individual's happiness and producing the morally mature, rational, self-disciplined adult.

A speculative point that this interpretation of character does not consider is the role of choice and decision. Several writers (Eucken, 1913, p. 365; Mouly, 1968, P. 455; White, 1890, p. 49, 1903a, p. 23) point out the necessity of this factor as important if character is to form effectively.

\section{Character as Ego Strength}

Peck and Havighurst (1960) define ego strength as the "capacity to react to events with accurate perception, appropriate emotions, and insight (p. 21)." Another interpretation of character is that it indicates strength of will. Hartshorne and May (1928-1930) and Peck and Havighurst (1960, p. 167) found a correlation between ego strength 
and moral character scores. Kohlberg (1964, pp.390, 391) noted five ego strength variables which contributed to moral conduct: (a) general intelligence, (b) tendency to anticipate future events and to choose the greater remote outcome over the lesser immediate outcome, (c) capacity to maintain stable, focused attention, (d) capacity to control unsolialized fantasies, and (e) self-esteem or satisfaction with the self and the environment.

Kohlberg (1964) 1isted a number of studies which support the just mentioned five ego strength variables. This writer found support for (a) general intelligence (Kohlberg, 1966, p. 15; White, 1888, p. 555, 1900, p. 333, 1948d, p. 606) and (e) self-esteem (Ligon, 1956, pp. 176-177; White, 1888, p. 477, 1898a, p. 668, 1961, p. 143).

\section{Age at Which Moral Character is Formed}

Most writers (Junel1, 1969, p. 450 quoting Allport, 1955, p. 33; Peck \& Havighurst, 1960, pp. 178-181; Pressey, 1957, p。 498; White, 1954, pp. 193, 194, 1958, p. 437, etc.) emphasize birth through 10 or 12 as the most important years of character formation. White (1954) stated:

Too much importance cannot be placed on the early training of children. The first lessons that the child learns during the first seven years of life have more to do with forming his character than all that it learns in future years (p. 193).

This statement is supported by Peck and Havighurst (1960) who wrote that "The most powerful, most persistent attitudes, perceptual sets, reaction patterns appear to be those learned in the first 10 years of life through moment by moment interaction of the home (p. 165)." 
Psychologists regard character structure as being relatively unalterable. Lapsley (1967) stated that "A response pattern may be modified to some extent, so as to be more adaptive, but the basic pattern cannot be radically changed (p. 52)." Peck and Havighurst (1960, p. 165), Pressey (1957, p. 498), and White (1954, pp. 199, 200) point out that attitudes, motives, and traits of character formed during the early years tend to be maintained through the years.

How can character be changed? White, presenting a religious viewpoint, maintains that character can be changed through the combining of human effort with Divine aid (1897b, 1911, pp. 475, 476, 482, 1917, p. 590, 1948e, p. 449). Paul, writing in Holy Scripture (Ephesians 3:20, Phillippians 4:13, 2 Corinthians 12:9), presents this change. Peck \& Havighurst (1960, p. 190) observed that deformed character can be changed in only one way--by close, prolonged association with someone who cares deeply and gives the nurturance of a good parent.

\section{Development of Mora1 Ideology and Judgment}

Havighurst (1965) stated that living in any society is a long series of tasks to learn, "where learning well brings satisfaction and reward, while learning poorly brings unhappiness and social disapproval (p. 2)." The child, from birth onward, is subject to a series of developmental tasks (i.e., learning to walk, talk, control elimination of body wastes, forming simple concepts of social and physical reality, etc.) that move from the simple to the complex. According to Havighurst (1965, pp. 23, 24) the middle childhood years 
(ages 6-12) is the period when the individual should develop conscience, morality, and a scale of values.

Most of the theoretical knowledge about character development is derived from Freud and Piaget. Kreps (1970) referring to Hoffman (1963) states that:

Freud's psychoanalytic theory is concerned with the emotional and motivational aspects of the personality structure. His research has provided the main pattern for most of the recent research on the role of parental practices in shaping the child's character. The main point of his theory is that sometime in early childhood the individual begins to model his behavior after that of his parents and through this process of identification the codes of conduct such as moral standards become a part of the child's own set of standards ( $p .9)$.

Character types in psychoanalytic thought have been identified by five stages of psychosexual development--oral, anal, phallic, 1atency, and genital. Lapsley (1967, pp. 51, 52) states that the dominant personality pattern of character is thought to be due to failure to adequately resolve conflicts during childhood stages of development. Hence, character has a defensive quality about it.

The theory which has most directly inspired recent research on moral judgment has been that of the psychologist Jean Piaget (1932). He views intellectual growth as a matter of sequential stages called schemas where the child learns to use increasingly difficult logical operations. The child's thought processes are categorized into four main schema:

$\underline{\text { Schema }}$

1. Sensori-motor Period

2. Preoperational Period

3. Concrete Operations Period

4. Formal Operations Period
Developmental Period

1. Birth to 2 years

2. 2 to 7 years

3. 7 to 11 years

4. 11 years onward 
In moral judgment, development is viewed as shifts from less mature to mature concepts. Piaget and his followers identified eleven different aspects of development of moral judgment. Six of them relate to the cognitive components of his schemas. They are (a) Intentionality in judgment, (b) Relativism in judgment, (c) Independence of sanctions, (d) Ese of reciprocity, (e) Use of punishment as restitution and reform, and (f) Naturalistic views of misfortune (Kohlberg, 1964, pp. 396-398). Kreps (1970) described Piaget's belief in how character develops through the four schemas as

(a) nonrecognition of rules, (b) recognition of rules as absolute and morally correct, as given by authority, (c) recognition of the conventional, arbitrary character of rules, and (d) manipulation of and recognition of the changeability of rules $(p, 9)$.

Peck and Havighurst (1960, p. 3) suggest that character involves

five different levels of development:

\section{Character Type}

1. Amoral

2. Expedient

3. Conforming

4. Irrational-Conscientious

5. Rational-Altruistic

\section{Developmental Period}

1. Infancy

2. Early Childhood

3. Later Childhood

4. Later Childhood

5. Adolescence and Adulthood

Each character type has a defined set of traits that are representative of the individual's psychosocial development. Kreps (1970) states:

these traits were intended to be defined and labeled in terms of the control system the individuals use to adapt their search for satisfaction to the requirements of the social world and also to represent both operational patterns of behavior and the stages in psychosocial development to which each pattern presumable is most appropriate (p. 10). 
Kohlberg's (1970) theory of character development is a hierarchial ordered sequence typology. He defines the moral stages along three levels:

I. Pre-Conventional Level

Stage 1: The punishment and obedience orientation. Stage 2: The instrumental relativist orientation.

II. Conventional Level

Stage 3: The interpersonal concordance or "good boynice girl" orientation.

Stage 4: The "law and order" orientation.

III. Post-Conventional, Autonomous, or Principled Level

Stage 5: The social-contract legalistic orientation. Stage 6: The universal ethical principle orientation (pp. 182, 183).

Kohlberg (1970) states that

Each step of development, . . . is a better cognitive organization than the one before it, one which takes account of everything present in the previous stage, but making new distinctions and organizing them into a more comprehensive or more equilibriated structure (p. 190).

He further identified twenty-five basic moral concepts or aspects which utilized the six stages. In "Motive Given for Rule Obedience or Moral Action," one concept, Kohlberg (1970) explained the six stages as:

Stage 1: Obeys rules to avoid punishment.

Stage 2: Conform to obtain rewards, have favors returned, and so on.

Stage 3: Conform to avoid disapproval, dislike by others.

Stage 4: Conform to avoid censure by legitimate authorities and resultant guilt.

Stage 5: Conform to maintain the respect of the impartial spectator judging in terms of community welfare.

Stage 6: Conform to avoid self-condemnation (p. 183). 


\section{Value Definitions}

The review of literature indicates that values and attitudes constitute basic components in the concept of character and appear under many names and in a variety of research contests. There is difficulty in defining the word "value." According to Raths, Harmin and Simon (1966):

The meaning of the term value is by no means clear in the social sciences or in philosophy. One can find consensus for no definition. About the only agreement that emerges is that a value represents something important in human existance ( $p, 9)$.

For Martin (1971) "a value is typically a single belief that guides actions and judgments across specific objects and situations and beyond immediate goals to more ultimate states of existence (pp. 6, 7)." Kreps (1970) quotes Gabrie1 (1968, pp. 62, 63) by. stating:

Values are means, among others, by which behavior is regulated when several choices or courses of action are available to a person. Values imply more than just choice, they imply that certain standards have been accepted by an individual - . are an integral part of the self-regarding sentiment (p.8).

This idea is reflected in Lee's (1959) definition:

By human values, by a value or a system of values, I mean the basis upon which an individual will choose one course rather than another, judged as better or worse, right or wrong. We can speak about human values, but we cannot know them directly. We infer them through their expression in behavior ( $p .165$ ).

In other words, values serve as a standard of judgment or a yardstick to guide actions, attitudes, comparisons, evaluations and justifications of the self and others.

Christenson and Dillman (1973), referring to the results of several studies (Calton, 1966; Dillman \& Christenson, 1972; Kluckhohn, 1959; Nye, 1967), stated: 
Both values and attitudes imply conceptions of the desirable but these concepts are different in two important aspects. Values are more general in nature than attitudes and imply hierarchical ordering. A particular value may encompass several specific concerns and attitudes ( $\mathrm{pp}, 4,5)$.

Values and attitudes are composed of reflected thought as well as feelings and emotional tones and subjective judgments. For this reason values generally are included in the category of learning called the affective domain (Torkelson, 1967). Raths, et al. (1966, p. 30) developed a criterion of seven elements for determining a value. These seven elements are divided into three processes, choosing, prizing, and acting, which reflect the levels found in Krathwohl's Taxonomy of Educational Objectives: Handbook II: Affective Domain:

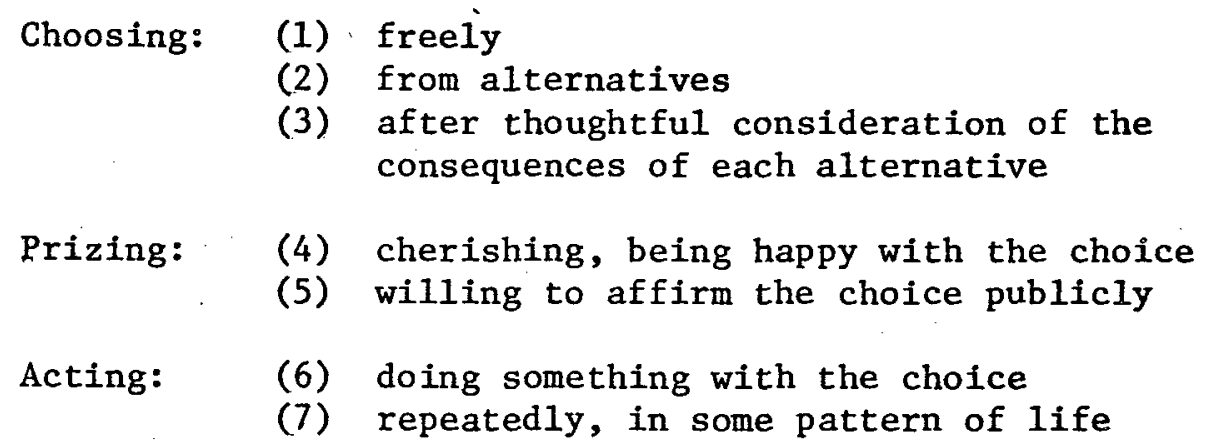

In summary, character has been defined by educators and researchers in terms of the individuals' values and attitudes. Values have been defined as "single belief," "standards," "a yardstick," "anything desired," and "something prized."

\section{Acquiring Values}

Havighurst (1965, p. 23) stated that the child is born without conscience and without a scale of values. The principal values for him are food and warmth. 
Torkelson (1967, p. 41) noted that attitudes and values are acquired in four ways: (a) adoption, (b) trauma, (c) differentiation, and (d) integration. Children acquire by adoption the values of the social milieu from which they have come. Junell (1969) who quotes Getzel (1958) states:

Values are not so much learned as they are "interiorized" through intimate and complex processes of identification in which the child strives to integrate and stabilize his own self-image by becoming "as one" with other persons--parents, older siblings, friends, teachers. The process is carried on for the most part unconsciously, on a level of feeling and emotion, and seldom if ever intellectualized. During the while the child assumes not only "the outward manners and expressive movements of his 'significant figures' but attempts also to incorporate their values and attitudes ( $p$. 450).

Wolfson (1967) agrees with this position. He wrote:

It has been suggested that he (the child) assimilated the values of his society and his home as unconsciously as he breathes the air around him. Possibly he imitates the values and attitudes he experiences in his home. When he gets into the larger society of neighborhood and school (and beyond), he may further imitate the values of those he admires. As some express it, he identifies with other individuals and accepts their values (p. 37).

Some children have also acquired values through traumatic experiences.

Torkelson (1967) points out that

It is much less likely that values will have been achieved by differentiation, the result of a general state of dissatisfaction; or by integration, a higher order of experience by which specific reactions are systematically generalized into a value complex (p. 41).

The child adopts values, interiorizing them through identi-

fication. It is here that the factors of example, teaching, discipline (reward and punishment) and choice are important. It has already been pointed out (in the section Character as Good Habits) that these factors are significant elements in character development. 
The child adopts values toward these factors (in the home, neighborhood, school, church, etc.) as they are satisfying to him. Junell (1969) stated ". . value arises out of the most satisfactory relationship between human needs and environmental conditions and that this involves choice (p. 450)." Other writers (Burroughs, 1967, p. 457; Mouly, 1968, pp. 455, 475; Pressey, 1957, p. 454) supply supporting statements concerning the need for satisfactory experiences. 
CHAPTER III

THE RESEARCH DESIGN

This is a study of the descriptive type using the Questioning Method and more specifically the Questionnaire.

\section{Population and Sample}

The population for this study were students enrolled in the College of Andrews University during the Spring Quarter of 1974. Two alphabetized rosters of student names, one male and one female, were obtained from the Undergraduate Records office. A 15 per cent sample, proportional stratified by sex, was obtained for this study using computer obtained numbers. A total of 205 subjects, 94 male and 111 female, constituted the original sample. A total of 185 subjects, 84 male and 101 female, represent a 90 per cent sample return, proportionally stratified by sex.

\section{Limitations}

One limitation was that the discussion of the findings to the SDA sample was qualified by the fact that randomization brought into the study adherents of other Protestant groups. A second limitation was that not all subjects replied to all questions: this resulted in variations of total sample responses in the analysis. 


\section{Instruments}

Positive Character Values List

The questionnaire used in this study (see Appendix 3), designed by Kreps (1970, pp. 53-57), was developed primarily to examine the attitudes of college students concerning values that are important in promoting positive character development in individuals.

The first part of the questionnaire was designed to obtain background information about each subject such as (a) sex, (b) age, (c) college classification, (d) college major, (e) race, (f) employment status of mother for major part of childhood, (g) religious preference, (h) residence, (i) siblings, (j) sibling position, (k) marital status of subject, (1) marital status of parents, (m) exposure to a family relations course, (n) socio-economic status, (o) prevailing type of discipline in family of orientation, and ( $p$ ) happiness of childhood relationships with parents.

The second part of the questionnaire, the Positive Character Values (PCV) List, was developed in order to obtain a list of values most often considered to promote positive character development and to fulfill human living. Kreps (1970, p. 26) developed the PCV list as a result of her review of literature on character. Basically, this 1ist was developed from the research of Havighurst and Taba (1949) and the 1ist of values presented by Ackerman (1958).

As an index of validity, Kreps (1970, p. 26) submitted the PVC Iist to a panel of eight family life specialists in order to determine the degree of agreement among the judges concerning the importance of the 1isted values as components of positive character 
development. The judges were asked to add any important values which they felt had been omitted. The percentage of agreement among the judges concerning the list of values as presented was 100 per cent. The final list of sixteen values which compose the PCV List are as follows:

1. Determination and Perseverance

2. Self-Reliance

3. Seeing Each Person as Having Dignity and Worth

4. Moral Courage (courage to stand by one $s$ inner convictions)

5. Spiritual Development

6. Cooperation

7. Honesty and Integrity

8. Loyalty

9. Self-Discipline

10. Feeling of Genuine Concern and Responsibility Toward Others

11. Initiative

12. Intellectual Inquisitiveness

13. Responsibility in Performing Tasks

14. Self-Respect

15. Friendliness

16. Appreciation

\section{McGuire-White Social Class Index}

The socio-economic class of each subject was determined by the McGuire-White Social Class Index (1955) as explained in Appendix 4. 


\section{Procedure}

Authorization to administer the questionnaire was obtained from the Office of Student Affairs in the undergraduate school of Andrews University. The dormitory subjects received a letter requesting their cooperation and the questionnaire either personally from this researcher or in their dormitory mailbox. Dormitory students deposited the completed questionnaire in a specified receptacle. Community students received the letter, the questionnaire, and a preaddressed and stamped envelope for returning the questionnaire either personally to this researcher or in an envelope through the mail. Names were omitted from the questionnaire in order to ensure more honest cooperation.

\section{Analysis of Data}

Percentages and frequencies of perceptions of college students are presented from the following:

1. Five values believed to be most important for parents to assist their children in learning in order to promote positive character development.

2. Three values which parents are most successful in helping their children learn.

3. Three values which parents most often fail to help their children learn.

4. The source of greater parental influence.

5. The source of greatest community influence on the development of character of children. 
6. The most effective manner in which the values involved in character development are learned.

7. The manner which parents most often use to help children learn values involved in positive character development.

The results of the questionnaire, the frequencies of perceptions, are compared on the basis of the Chi-square test. The Chi-square test was used to examine all the non-directional null hypotheses. The hypotheses were rejected at a probability level of .05 . 
CHAPTER IV

PRESENTATION AND ANALYSIS OF DATA

\section{Introduction}

This chapter presents the data obtained from the questionnaires returned by 185 college students randomly selected from the campus of a church related university. Chapter $V$ presents a discussion of possible reasons why selected perceptions concerning character development were chosen and compares the responses with the responses in the Kreps (1970) study.

\section{Description of the Subjects}

A detailed description of the 185 respondents who participated in this study is presented in Table 1. This sample, proportionally stratified by sex, consisted of 45.5 per cent males and 54.6 per cent females. The greatest percentage $(35.1 \%)$ in the age variable were the 19-20 year olds. The largest percentage of the subjects in the college classification variable were college seniors (31.3\%). The largest proportion of the subjects $(37.3 \%)$ were pursuing a course of study in technology. A majority of the subjects (82.2\%) were white. Most subjects (63.8\%) reported their mother not being employed for the major part of their childhood. The majority of the subjects were Protestant (94.0\%) with a stated 86.5 per cent Seventh-day Adventist. Over half of the respondents had lived most of their lives on a 
TABLE 1

CHARACTERISTICS OF THE SUBJECTS

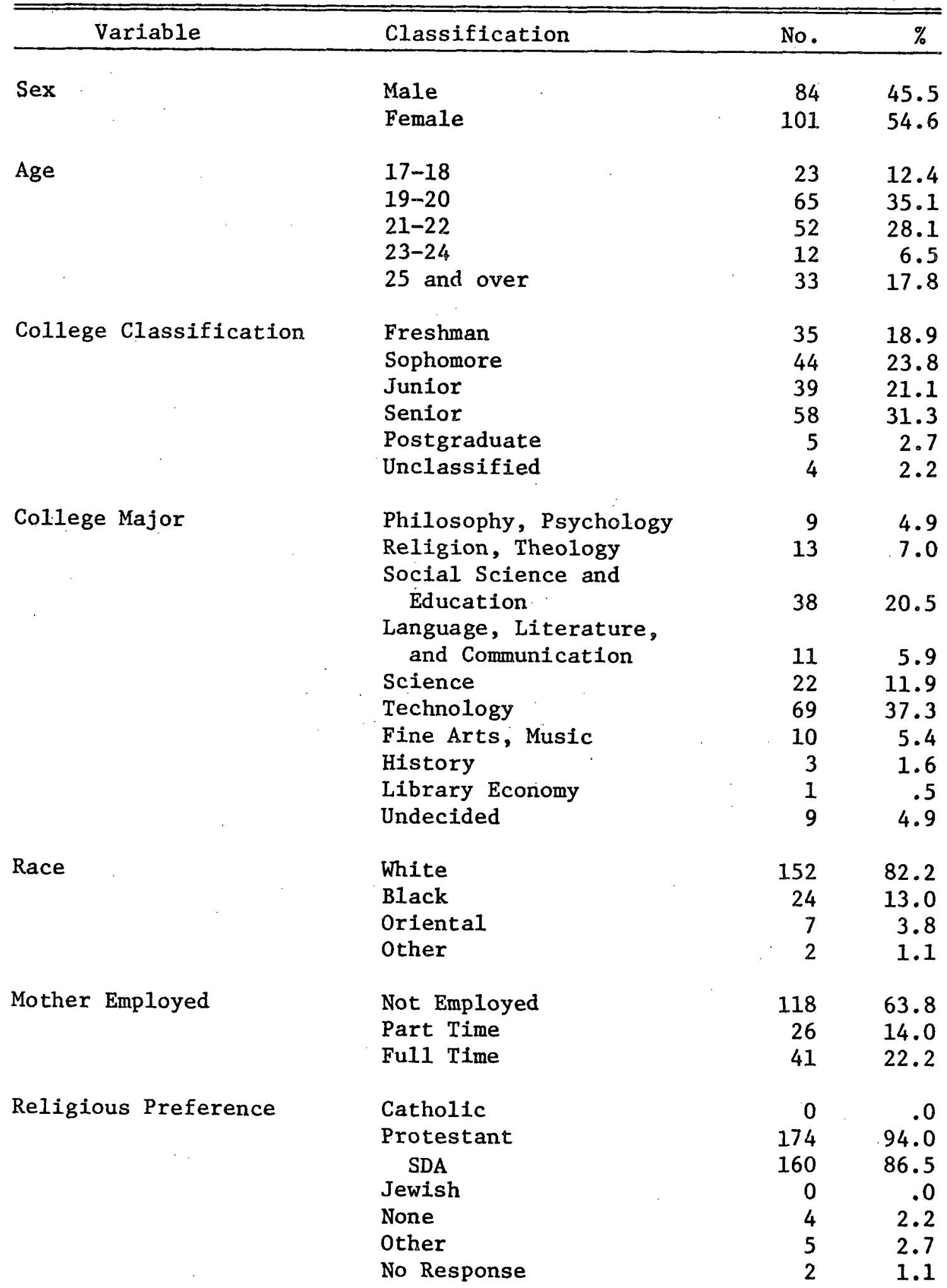


TABLE 1 (Continued)

\begin{tabular}{|c|c|c|c|}
\hline Variable & Classification & No. & $\%$ \\
\hline Residence & $\begin{array}{l}\text { Farm } \\
\text { Under } 25,000 \\
25,000-50,000 \\
50,000-100,000 \\
\text { Over } 100,000\end{array}$ & $\begin{array}{l}55 \\
46 \\
30 \\
29 \\
25\end{array}$ & $\begin{array}{l}29.7 \\
24.9 \\
16.2 \\
15.7 \\
13.5\end{array}$ \\
\hline Brothers or Sisters & $\begin{array}{l}\text { Yes } \\
\text { No }\end{array}$ & $\begin{array}{r}180 \\
5\end{array}$ & $\begin{array}{r}97.3 \\
2.7\end{array}$ \\
\hline Ordinal Position & $\begin{array}{l}\text { Oldest Child } \\
\text { Intermediate Child } \\
\text { Youngest Child }\end{array}$ & $\begin{array}{l}62 \\
74 \\
44\end{array}$ & $\begin{array}{l}33.5 \\
40.0 \\
23.8\end{array}$ \\
\hline $\begin{array}{l}\text { Marital Status } \\
\text { (Subjects) }\end{array}$ & $\begin{array}{l}\text { Single } \\
\text { Married } \\
\text { Divorced } \\
\text { Separated } \\
\text { Widowed } \\
\text { No Response }\end{array}$ & $\begin{array}{r}145 \\
38 \\
0 \\
0 \\
1 \\
1\end{array}$ & $\begin{array}{r}78.4 \\
20.5 \\
.0 \\
.0 \\
.5 \\
.5\end{array}$ \\
\hline $\begin{array}{l}\text { Parents! Marital } \\
\text { Status }\end{array}$ & $\begin{array}{l}\text { Living Together } \\
\text { Separated or Divorced } \\
\text { One Parent Deceased } \\
\text { (No Remarriage) } \\
\text { Divorced (Remarriage) } \\
\text { One Parent Deceased } \\
\text { (With Remarriage) } \\
\text { No Response }\end{array}$ & $\begin{array}{r}151 \\
6 \\
7 \\
7 \\
16 \\
4 \\
1\end{array}$ & $\begin{array}{r}81.6 \\
3.2 \\
3.8 \\
8.6 \\
2.2 \\
.5\end{array}$ \\
\hline Family Relations Course & $\begin{array}{l}\text { Yes } \\
\text { No }\end{array}$ & $\begin{array}{r}81 \\
104\end{array}$ & $\begin{array}{l}43.8 \\
56.2\end{array}$ \\
\hline Socio-Economic Status & $\begin{array}{l}\text { Upper } \\
\text { Upper Middle } \\
\text { Lower Middle } \\
\text { Upper Lower } \\
\text { Lower Lower } \\
\text { No Response }\end{array}$ & $\begin{array}{r}16 \\
69 \\
53 \\
33 \\
3 \\
11\end{array}$ & $\begin{array}{r}8.6 \\
37.3 \\
28.6 \\
17.8 \\
1.6 \\
5.9\end{array}$ \\
\hline Type of Discipline & $\begin{array}{lll}1 & \text { Very Permissive } \\
2 & & \\
3 & \\
4 & & \\
5 & & \text { to } \\
6 & & \\
7 & \\
8 & \\
9 & \text { Very Strict } \\
\text { No Response }\end{array}$ & $\begin{array}{r}0 \\
1 \\
2 \\
11 \\
44 \\
29 \\
65 \\
29 \\
3 \\
1\end{array}$ & $\begin{array}{r}.0 \\
.5 \\
1.1 \\
5.9 \\
23.8 \\
15.7 \\
35.1 \\
15.7 \\
1.6 \\
.5\end{array}$ \\
\hline
\end{tabular}


TABLE 1 (Continued)

\begin{tabular}{llrr}
\hline \multicolumn{1}{c}{ Variable } & Classification & No. & $\%$ \\
\hline Relationship with Parents & & & \\
during Childhood & Very Happy & 61 & 33.0 \\
& Happy & 93 & 50.3 \\
& Undecided & 19 & 10.2 \\
& Unhappy & 7 & 3.8 \\
& Very Unhappy & 3 & 1.6 \\
& No Response & 2 & 1.1 \\
\hline
\end{tabular}


farm $(29.7 \%)$ or in a sma11 town $(24.9 \%)$. The majority of the subjects (97.3\%) reported having brothers and sisters. Of those subjects with other siblings, the largest proportion (40.0\%) were the intermediate child in the family. A majority of the subjects (78.4\%) in the marital status variable were single. The highest proportion of the respondents (81.6\%) reported their parents to be living together. Over half of the subjects (56.2\%) had not taken a family relations course. The greatest percentage of the respondents were classified as upper middle class as measured by McGuire-White Social Class Index (1955). The greatest percentage $(35.1 \%)$ of the subjects perceive a fairly strict type of discipline used toward them by their parents. Over half of the subjects $(50.3 \%)$ reported that the relationship held with their parents during childhood was happy.

\section{Analysis of Perceptions}

Selected perceptions concerning character development and values important to the development of positive character development were examined. Examined were perceptions concerning:

1. The five values believed to be most important for parents to assist their children in learning in order to promote positive character development.

2. The three values which parents are most successful in helping their children learn.

3. The three values which parents most often fail to help their children learn.

4. The source of greater parental influence. 
5. The source of greatest community influence on the child's character development.

6. The most effective manner in which the values involved in character development are learned.

7. The manner which parents most often use to help children learn values involves in positive character development.

As Table 2 shows, the five values which had the highest rate of selection as values most important for parents to assist children in learning are as follows: Spiritual Development (16.5\%), Honesty and Integrity (13.1\%), Seeing Each Person as Having Dignity and Worth (11.5\%), Self-Discipline (8.5\%), and Moral Courage (8.3\%).

As illustrated in Table 3, values which had the highest rate of selection as values parents are most successful in helping children learn are Self-Reliance (16.2\%), Determination (8.6\%), and Intellectual Inquisitiveness (8.3\%).

As shown in Table 4, the three values which had the highest rate of selection as values parents most often fail to help children learn are Spiritual Development (18.9\%), Self-Discipline (11.4\%), and Seeing Each Person as Having Dignity and Worth (10.1\%).

The majority of the subjects $(76.7 \%)$ in Table 5 reported the Mother to be the more important parent in influencing the character development of children.

As Table 6 shows, the Family was selected by the majority of the respondents $(73.5 \%)$ as the community influence that has the greatest influence on the child's character development. 
TABLE 2

PERCEPTIONS CONCERNING THE MOST IMPORTANT VALUES FOR PARENTS TO ASSIST THEIR CHILDREN IN LEARNING IN ORDER TO PROMOTE POSITIVE CHARACTER DEVELOPMENT

\begin{tabular}{|c|c|c|c|c|c|c|}
\hline \multirow{2}{*}{$\begin{array}{l}\text { Perceptions of Most } \\
\text { Important Values }\end{array}$} & \multicolumn{2}{|c|}{ Male } & \multicolumn{2}{|c|}{ Female } & \multicolumn{2}{|c|}{ Total } \\
\hline & No. & $\%$ & No. & $\%$ & No. & $\%$ \\
\hline Spiritual Development & 66 & 15.7 & 87 & 17.2 & 153 & 16.5 \\
\hline Honesty and Integrity & 53 & 12.6 & 68 & 13.5 & 121 & 13.1 \\
\hline $\begin{array}{l}\text { Seeing Each Person as } \\
\text { Having Dignity and Worth }\end{array}$ & 41 & 9.8 & 65 & 12.9 & 106 & 11.5 \\
\hline Self-Discipline & 36 & 8.6 & 43 & 8.5 & 79 & 8.5 \\
\hline Moral Courage & 38 & 9.0 & 39 & 7.7 & 77 & 8.3 \\
\hline $\begin{array}{l}\text { Genuine Concern and } \\
\text { Responsibility Toward Others }\end{array}$ & 25 & 6.0 & 39 & 7.7 & 64 & 6.9 \\
\hline $\begin{array}{l}\text { Responsibility in } \\
\text { Performing Tasks }\end{array}$ & 28 & 6.7 & 32 & 6.3 & 60 & 6.5 \\
\hline Self-Respect & 22 & 5.2 & 36 & 7.1 & 58 & 6.3 \\
\hline Determination & 22 & 5.2 & 17 & 3.4 & 39 & 4.2 \\
\hline Intellectual Inquisitiveness & 20 & 4.8 & 14 & 2.8 & 34 & 3.7 \\
\hline Friendliness & 16 & 3.8 & 15 & 3.0 & 31 & 3.4 \\
\hline Self-Reliance & 14 & 3.3 & 13 & 2.6 & 27 & 2.9 \\
\hline Appreciation & 11 & 2.6 & 13 & 2.6 & 24 & 2.6 \\
\hline Initiative & 10 & 2.4 & 11 & 2.2 & 21 & 2.3 \\
\hline Cooperation & 8 & 1.9 & 5 & 1.0 & 13 & 1.4 \\
\hline Loyalty & 5 & 1.2 & 3 & .6 & 8 & .9 \\
\hline No Response & 5 & 1.2 & 5 & 1.0 & 10 & 1.1 \\
\hline
\end{tabular}


TABLE 3

PERCEPTIONS OF VALUES PARENTS ARE MOST SUCCESSFUL IN HELPING THEIR CHILDREN LEARN

\begin{tabular}{|c|c|c|c|c|c|c|}
\hline \multirow{2}{*}{$\begin{array}{l}\text { Perceptions of Values Parents } \\
\text { are Most Successful With }\end{array}$} & \multicolumn{2}{|c|}{ Male } & \multicolumn{2}{|c|}{ Female } & \multicolumn{2}{|c|}{ Total } \\
\hline & No. & $\%$ & No. & $\%$ & No. & $\%$ \\
\hline Self-Relfance & 45 & 17.9 & 45 & 14.9 & 90 & 16.2 \\
\hline Determination & 15 & 6.0 & 33 & 10.9 & 48 & 8.6 \\
\hline Intellectual Inquisitiveness & 26 & 10.3 & 20 & 6.6 & 46 & 8.3 \\
\hline Friendliness & 29 & 11.5 & 16 & 5.3 & 45 & 8.1 \\
\hline Self-Respect & 19 & 7.5 & 20 & 6.6 & 39 & 7.0 \\
\hline Moral Courage & 20 & 7.9 & 17 & 5.6 & 37 & 6.7 \\
\hline Cooperation & 15 & 6.0 & 17 & 5.6 & 32 & 5.8 \\
\hline $\begin{array}{l}\text { Responsibility in } \\
\text { Performing Tasks }\end{array}$ & 8 & 3.2 & 23 & 7.6 & 31 & 5.6 \\
\hline Initiative & 14 & 5.6 & 15 & 5.0 & 29 & 5.2 \\
\hline $\begin{array}{l}\text { Seeing Each Person as } \\
\text { Having Dignity and Worth }\end{array}$ & 7 & 2.8 & 20 & 6.6 & 27 & 4.9 \\
\hline Honesty and Integrity & 9 & 3.6 & 16 & 5.3 & 25 & 4.5 \\
\hline Loyalty & 11 & 4.4 & 13 & 4.3 & 24 & 4.3 \\
\hline Spiritual Development & 8 & 3.2 & 15 & 5.0 & 23 & 4.1 \\
\hline $\begin{array}{l}\text { Genuine Concern and Responsi- } \\
\text { bility Toward Others }\end{array}$ & 6 & 2.4 & 13 & 4.3 & 19 & 3.4 \\
\hline Self-Discipline & 5 & 2.0 & 6 & 2.0 & 11 & 2.0 \\
\hline Appreciation & 8 & 3.2 & 3 & 1.0 & 11 & 2.0 \\
\hline No Response & 7 & 2.8 & 11 & 3.6 & 18 & 3.2 \\
\hline
\end{tabular}


TABLE 4

PERCEPTIONS OF THE VALUES PARENTS MOST OFTEN FAIL TO HELP CHLLDREN LEARN

\begin{tabular}{|c|c|c|c|c|c|c|}
\hline \multirow{2}{*}{$\begin{array}{l}\text { Perceptions of Values Parents } \\
\text { Most Often Fail With }\end{array}$} & \multicolumn{2}{|c|}{ Male } & \multicolumn{2}{|c|}{ Female } & \multicolumn{2}{|c|}{ Total } \\
\hline & No. & $\%$ & No. & $\%$ & No. & $\%$ \\
\hline Spiritual Development & 49 & 19.4 & 56 & 18.5 & 105 & 18.9 \\
\hline Self-Discipline & 22 & 8.7 & 41 & 13.5 & 63 & 11.4 \\
\hline $\begin{array}{l}\text { Seeing Each Person as } \\
\text { Having Dignity and Worth }\end{array}$ & 25 & 9.9 & 31 & 10.2 & 56 & 10.1 \\
\hline Moral Courage & 23 & 9.1 & 32 & 10.6 & 55 & 9.9 \\
\hline Honesty and Integrity & 23 & 9.1 & 31 & 10.2 & 54 & 9.7 \\
\hline $\begin{array}{l}\text { Genuine Concern and Responsi- } \\
\text { bility Toward Others }\end{array}$ & 30 & 11.9 & 20 & 6.6 & 50 & 9.0 \\
\hline Appreciation & 10 & 4.0 & 20 & 6.6 & 30 & 5.4 \\
\hline $\begin{array}{l}\text { Responsibility in } \\
\text { Performing Tasks }\end{array}$ & 16 & 6.3 & 13 & 4.3 & 29 & 5.2 \\
\hline Self-Respect & 9 & 3.6 & 10 & 3.3 & 19 & 3.4 \\
\hline Self-Reliance & 8 & 3.2 & 9 & 3.0 & 17 & 3.1 \\
\hline Initiative & 6 & 2.4 & 11 & 3.6 & 17 & 3.1 \\
\hline Determination & 9 & 3.6 & 7 & 2.3 & 16 & 2.9 \\
\hline Cooperation & 7 & 2.8 & 9 & 3.0 & 16 & 2.9 \\
\hline Intellectual Inquisitiveness & 6 & 2.4 & 6 & 2.0 & 12 & 2.2 \\
\hline Friendliness & 4 & 1.6 & 3 & 1.0 & 7 & 1.3 \\
\hline Loyalty & 5 & 2.0 & 1 & .3 & 6 & 1.1 \\
\hline No Response & 0 & .0 & 3 & 1.0 & 3 & .5 \\
\hline
\end{tabular}


TABLE 5

PERCEPTIONS OF THE SOURCE OF GREATER PARENTAL INFLUENCE ON CHARACTER DEVELOPMENT

\begin{tabular}{|c|c|c|c|c|c|c|}
\hline \multirow[b]{2}{*}{ Parental Influence } & \multicolumn{2}{|c|}{ Male } & \multicolumn{2}{|c|}{ Female } & \multicolumn{2}{|c|}{ Total } \\
\hline & No. & $\%$ & No. & $\%$ & No. & $\%$ \\
\hline Mother & 63 & 75.0 & 79 & 78.2 & 142 & 76.7 \\
\hline Father & 9 & 10.7 & 7 & 6.9 & 16 & 8.6 \\
\hline No Response & 12 & 14.3 & 15 & 14.8 & 27 & 14.6 \\
\hline
\end{tabular}

TABLE 6

PERCEPTIONS OF GREATEST COMMUNITY INFLUENCE ON CHARACTER DEVELOPMENT

\begin{tabular}{|c|c|c|c|c|c|c|}
\hline \multirow{2}{*}{$\begin{array}{l}\text { Perceptions of Greatest } \\
\text { Community Influence }\end{array}$} & \multicolumn{2}{|c|}{ Male } & \multicolumn{2}{|c|}{ Female } & \multicolumn{2}{|c|}{ Total } \\
\hline & No. & $\%$ & No. & $\%$ & No. & $\%$ \\
\hline School & 8 & 9.5 & 6 & 5.9 & 14 & 7.6 \\
\hline Church & 3 & 3.6 & 3 & 3.0 & 6 & 3.2 \\
\hline Family & 60 & 71.4 & 76 & 75.2 & 136 & 73.5 \\
\hline Peers & 11. & 13.1 & 16 & 15.8 & 27 & 14.6 \\
\hline No Response & $2:$ & 2.4 & 0 & .0 & 2 & 1.1 \\
\hline
\end{tabular}


Respondents, in Table 7, selected Example and Models (41.4\%) most frequently as the most effective manner in which values involved in character development are learned.

As Table 8 indicates, Reward and Punishment was selected most frequently $(73.0 \%)$ as the manner which parents most often use to help children learn values involved in character development.

\section{Data Pertaining to the Hypotheses}

Tables 9-39 present the data frequencies used for chi-square analysis. Yates's correction for continuity was used if any expected frequency was less than 5. The obtained value of $\chi^{2}$ was compared against the critical chi-square for $\alpha=.05$.

\section{Examination of Hypotheses}

Hypothesis 1

There is no significant difference in perceptions concerning the source of greater parental influence on the character development of children when respondents are classified according to (a) sex, (b) age, (c) race, (d) employment status of mother, (e) residence, (f) marital status of parents, (g) socio-economic class, and (h) happiness of childhood relationship with parents. Each of these eight sub-hypotheses was supported.

Hypothesis 2 ,

There is no significant difference in perceptions concerning the source of greatest community influence on the character development of children when respondents are classified according to (a) sex, (b) age, (c) race, (d) employment status of mother, (e) residence, 
TABLE 7

PERCEPTIONS OF THE MOST EFFECTIVE MANNER IN WHICH VALUES INVOLVED IN CHARACTER DEVELOPMENT ARE LEARNED

\begin{tabular}{|c|c|c|c|c|c|c|}
\hline \multirow{2}{*}{$\begin{array}{l}\text { Perceptions of Most } \\
\text { Effective Manner }\end{array}$} & \multicolumn{2}{|c|}{ Male } & \multicolumn{2}{|c|}{ Female } & \multicolumn{2}{|c|}{ Total } \\
\hline & No. & $\%$ & No. & $\%$ & No. & $\%$ \\
\hline Reward and Punishment & 10 & 11.9 & 21 & 20.8 & 31 & 16.8 \\
\hline Example and Models & 35 & 41.2 & 41 & 40.6 & 76 & 41.1 \\
\hline $\begin{array}{l}\text { Realizing Consequences } \\
\text { of Behavior }\end{array}$ & 33 & 39.3 & 31 & 30.7 & 64 & 34.6 \\
\hline Other & 6 & 7.1 & 6 & 5.9 & 12 & 6.5 \\
\hline No Response & 0 & .0 & 2 & 2.0 & 2 & 1.1 \\
\hline
\end{tabular}

TABLE 8

PERCEPTIONS OF THE MANNER WHICH PARENTS MOST OFTEN USE TO HELP CHILDREN LEARN VALUES INVOLVED IN CHARACTER DEVELOPMENT

\begin{tabular}{|c|c|c|c|c|c|c|}
\hline \multirow{2}{*}{$\begin{array}{l}\text { Perception of } \\
\text { Manner }\end{array}$} & \multicolumn{2}{|c|}{ Male } & \multicolumn{2}{|c|}{ Female } & \multicolumn{2}{|c|}{ Total } \\
\hline & No. & $\%$ & No. & $\%$ & No. & $\%$ \\
\hline Reward and Punishment & 58 & 69.0 & 77 & 76.2 & 135 & 73.0 \\
\hline Example and Model & 8 & 9.5 & 8 & 7.9 & 16 & 8.6 \\
\hline $\begin{array}{l}\text { Realizing Consequences } \\
\text { of Behavior }\end{array}$ & 13 & 15.5 & 11 & 10.9 & 24 & 13.0 \\
\hline Other & 3 & 3.6 & 3 & 3.0 & 6 & 3.2 \\
\hline No Response & 2 & 2.4 & 2 & 2.0 & 4 & 2.2 \\
\hline
\end{tabular}


TABLE 9

GREATER PARENTAL INFLUENCE AND SEX

\begin{tabular}{lccc}
\hline & Male & Female & Total \\
\hline Mother & 63 & 79 & 142 \\
Father & 9 & 7 & 16 \\
\hline Total & 72 & 86 & 158 \\
\hline
\end{tabular}

Obtained $x^{2}=0.82$ with $1 \mathrm{df}$.

Critical $\chi^{2}=3.84 \quad p>.05$

TABLE 10

GREATER PARENTAL INFLUENCE AND AGE

\begin{tabular}{lcccccc}
\hline & $17-18$ & $19-20$ & $21-22$ & $23-24$ & $25+$ & Total \\
\hline Mother & 17 & 49 & 42 & 9 & 25 & 142 \\
Father & 5 & 3 & 4 & 2 & 2 & 16 \\
\hline Total & 22 & 52 & 46 & 11 & 27 & 158 \\
\hline
\end{tabular}

Obtained $x^{2}=3.41$ with $4 \mathrm{df}$.

Critical $\chi^{2}=9.49 \quad \mathrm{p}>.05$

TABLE 11

GREATER PARENTAL INFLUENCE AND RACE

\begin{tabular}{lccccc}
\hline & White & Black & Oriental & Other & Total \\
\hline Mother & 115 & 20 & 5 & 2 & 142 \\
Father & 15 & 0 & 1 & 0 & 16 \\
\hline Total & 130 & 20 & 6 & 2 & 158 \\
\hline
\end{tabular}

Obtained $\chi^{2}=1.94$ with $3 \mathrm{df}$.

Critical $\chi^{2}=7.82 \quad p>.05$ 
TABLE 12

GREATER PARENTAL INFLUENCE AND MOTHER EMPLOYMENT

\begin{tabular}{|c|c|c|c|c|}
\hline & No & Part Time & Full Time & Total \\
\hline Mother & 86 & 35 & 21 & 142 \\
\hline Father & 13 & 1 & 2 & 16 \\
\hline Total & 99 & 36 & 23 & 158 \\
\hline
\end{tabular}

TABLE 13

GREATER PARENTAL INFLUENCE AND RESIDENCE

\begin{tabular}{lcccccc}
\hline & Farm & $\begin{array}{r}\text { Under } \\
25,000\end{array}$ & $\begin{array}{c}25,000- \\
50,000\end{array}$ & $\begin{array}{r}50,000- \\
100,000\end{array}$ & $\begin{array}{c}\text { Over } \\
100,000\end{array}$ & Total \\
\hline Mother & 44 & 36 & 26 & 19 & 17 & 142 \\
Father & 2 & 5 & 1 & 4 & 4 & 16 \\
\hline Total & 46 & 41 & 27 & 23 & 21 & 158 \\
\hline
\end{tabular}

obtained $\chi^{2}=3.41$ with $4 \mathrm{df}$.

Critical $\chi^{2}=9.49 \quad \mathrm{p}>.05$

TABLE 14

GREATER PARENTAL INFLUENCE AND PARENTS' MARITAL STATUS

\begin{tabular}{|c|c|c|c|c|c|c|}
\hline$\therefore$ & $\begin{array}{l}\text { Living } \\
\text { Together }\end{array}$ & $\begin{array}{l}\text { Separated- } \\
\text { Divorced }\end{array}$ & $\begin{array}{c}\text { One } \\
\text { Deceased } \\
\text { No } \\
\text { Remarriage }\end{array}$ & $\begin{array}{c}\text { Divorced } \\
\text { Remarriage }\end{array}$ & $\begin{array}{c}\text { One } \\
\text { Deceased } \\
\text { Remarriage }\end{array}$ & Total \\
\hline Mother & 113 & 6 & 6 & 12 & 4 & 141 \\
\hline Father & 14 & 0 & 0 & 2 & 0 & 16 \\
\hline Total & 127 & 6 & 6 & 14 & 4 & 157 \\
\hline
\end{tabular}


TABLE 15

GREATER PARENTAL INFLUENCE AND SOCIO-ECONOMIC STATUS

\begin{tabular}{lcccccc}
\hline \hline & Upper & $\begin{array}{r}\text { Upper } \\
\text { Middle }\end{array}$ & $\begin{array}{r}\text { Lower } \\
\text { Middle }\end{array}$ & $\begin{array}{r}\text { Upper } \\
\text { Lower }\end{array}$ & $\begin{array}{r}\text { Lower } \\
\text { Lower }\end{array}$ & Total \\
\hline Mother & 12 & 52 & 37 & 29 & 2 & 132 \\
Father & 1 & 9 & 4 & 1 & 1 & 16 \\
\hline Total & 13 & 61 & 41 & 30 & 3 & 148 \\
\hline
\end{tabular}

Obtained $x^{2}=1.78$ with $4 \mathrm{df}$

Critical $\chi^{2}=9.49 \quad$ p $>.05$

TABLE 16

GREATER PARENTAL INFLUENCE AND RELATIONSHIP WITH PARENTS

\begin{tabular}{lcccccc}
\hline \hline & $\begin{array}{c}\text { Very } \\
\text { Happy }\end{array}$ & Happy & Undecided & Unhappy & $\begin{array}{c}\text { Very } \\
\text { Unhappy }\end{array}$ & Total \\
\hline Mother & 50 & 70 & 12 & 6 & 3 & 141 \\
Father & 3 & 9 & 3 & 1 & 0 & 16 \\
\hline Total & 53 & 79 & 15 & 7 & 3 & 157 \\
\hline
\end{tabular}

Obtained $x^{2}=1.67$ with $4 \mathrm{df}$.

Critical $x^{2}=9.49 \quad \mathrm{p}>.05$ 
TABLE 17

GREATEST COMMUNITY INFLUENCE AND SEX

\begin{tabular}{lccr}
\hline & Male & Female & Total \\
\hline School & 8 & 6 & 14 \\
Church & 3 & 3 & 6 \\
Fami1y & 60 & 76 & 136 \\
Peers & 11 & 16 & 27 \\
\hline Total & 82 & 101 & 183 \\
\hline
\end{tabular}

Obtained $\chi^{2}=0.52$ with $3 \mathrm{df}$.

Critical $x^{2}=7.82 \quad \mathrm{p}>.05$

TABLE 18

GREATEST COMMUNITY INFLUENCE AND AGE

\begin{tabular}{lrrrrrr}
\hline \hline & $17-18$ & $19-20$ & $21-22$ & $23-24$ & $25+$ & Total \\
\hline School & 2 & 6 & 3 & 0 & 3 & 14 \\
Church & 2 & 2 & 2 & 0 & 0 & 6 \\
Family & 14 & 45 & 37 & 12 & 28 & 136 \\
Peers & 5 & 12 & 8 & 0 & 2 & 27 \\
\hline Total & 23 & 65 & 50 & 12 & 33 & 183 \\
\hline
\end{tabular}

Obtained $x^{2}=5.94$ with $12 \mathrm{df}$.

Critical $x^{2}=21.03$

$\mathrm{p}>.05$ 
TABLE 19

GREATEST COMMUNITY INFLUENCE AND RACE

\begin{tabular}{lrrccr}
\hline & White & Black & Oriental & Other & Tota1 \\
\hline School & 13 & 1 & 0 & 0 & 14 \\
Church & 5 & 1 & 0 & 0 & 6 \\
Family & 111 & 18 & 6 & 1 & 136 \\
Peers & 21 & 4 & 1 & 1 & 27 \\
\hline Total & 150 & 24 & 7 & 2 & 183 \\
\hline
\end{tabular}

Obtained $x^{2}=4.67$ with $9 \mathrm{df}$.

Critical $x^{2}=16.92 \quad \mathrm{p}>.05$

TABLE 20

GREATEST COMMUNITY INFLUENCE AND MOTHER EMPLOYMENT

\begin{tabular}{lrccr}
\hline \hline & No & Part Time & Full Time & Total \\
\hline School & 9 & 4 & 1 & 14 \\
Church & 3 & 3 & 0 & 6 \\
Family & 87 & 26 & 23 & 136 \\
Peers & 17 & 8 & 2 & 27 \\
\hline Total & 116 & 41 & 26 & 183 \\
\hline
\end{tabular}

Obtained $\chi^{2}=3.20$ with $6 \mathrm{df}$.

Critical $\chi^{2}=12.59 \quad \mathrm{p}>.05$ 
TABLE 21

GREATEST COMMUNITY INFLUENCE AND RESIDENCE

\begin{tabular}{|c|c|c|c|c|c|c|}
\hline & Farm & $\begin{array}{r}\text { Under } \\
25,000\end{array}$ & $\begin{array}{l}25,000 \\
50,000\end{array}$ & $\begin{array}{r}50,000 \\
100,000\end{array}$ & $\begin{array}{c}\text { Over } \\
100,000\end{array}$ & Total \\
\hline School & 5 & 5 & 3 & 1 & 0 & 14 \\
\hline Church & 2 & 1 & 1 & 2 & 0 & 6 \\
\hline Family & 43 & 34 & 21 & 19 & 19 & 136 \\
\hline Peer & 5 & 6 & 4 & 6 & 6 & 27 \\
\hline Total & 55 & 46 & 29 & 28 & 25 & 183 \\
\hline
\end{tabular}

Obtained $\chi^{2}=4.68$ with $12 \mathrm{df}$.

Critical $\chi^{2}=21.03 \quad \mathrm{p}>.05$

TABLE 22

GREATEST COMMUNITY INFLUENCE AND PARENTS' MARITAL STATUS

\begin{tabular}{|c|c|c|c|c|c|c|}
\hline & $\begin{array}{l}\text { Living } \\
\text { Together }\end{array}$ & $\begin{array}{c}\text { Separated- } \\
\text { Divorced }\end{array}$ & $\begin{array}{c}\text { One } \\
\text { Deceased } \\
\text { No } \\
\text { Remarriage }\end{array}$ & $\begin{array}{l}\text { Divorced } \\
\text { Remarriage }\end{array}$ & $\begin{array}{c}\text { One } \\
\text { Deceased } \\
\text { Remarriage }\end{array}$ & Total \\
\hline School & 10 & 0 & 1 & 2 & 1 & 14 \\
\hline Church & 5 & 0 & 0 & 1 & 0 & 6 \\
\hline Family & 110 & 5 & 6 & 11 & 3 & 135 \\
\hline Peer & 24 & .1 & 0 & 2 & 0 & 27 \\
\hline Total & 149 & 6 & 7 & 16 & 4 & 182 \\
\hline
\end{tabular}

Obtained $\chi^{2}=2.77$ with 12 df.

Critical $x^{2}=21.03 \quad \mathrm{p}>.05$ 
TABLE 23

GREATEST COMMUNITY INFLUENCE AND SOCIO-ECONOMIC STATUS

\begin{tabular}{lcccccc}
\hline & Upper & $\begin{array}{r}\text { Upper } \\
\text { Middle }\end{array}$ & $\begin{array}{r}\text { Lower } \\
\text { Middle }\end{array}$ & $\begin{array}{r}\text { Upper } \\
\text { Lower }\end{array}$ & $\begin{array}{r}\text { Lower } \\
\text { Lower }\end{array}$ & Total \\
\hline School & 0 & 5 & 4 & 2 & 1 & 12 \\
Church & 0 & 4 & 1 & 1 & 0 & 6 \\
Family & 12 & 51 & 38 & 25 & 2 & 128 \\
Peer & 4 & 8 & 9 & 5 & 0 & 26 \\
\hline Total & 16 & 68 & 52 & 33 & 3 & 172 \\
\hline
\end{tabular}

Obtained $\chi^{2}=3.92$ with $12 \mathrm{df}$.

Critical $\chi^{2}=21.03$ p $>.05$

TABLE 24

GREATEST COMMUNITY INFLUENCE AND RELATIONSHIP WITH PARENTS

\begin{tabular}{lrrrccr}
\hline & $\begin{array}{r}\text { Very } \\
\text { Happy }\end{array}$ & Happy & Undecided & Unhappy & $\begin{array}{c}\text { Very } \\
\text { Unhappy }\end{array}$ & Total \\
\hline School & 2 & 9 & 1 & 1 & 1 & 14 \\
Church & 0 & 6 & 0 & 0 & 0 & 6 \\
Family & 49 & 64 & 14 & 6 & 2 & 135 \\
Peers & 9 & 14 & 3 & 0 & 0 & 26 \\
\hline \multirow{2}{*}{ Total } & 60 & 93 & 18 & 7 & 3 & 181 \\
\hline
\end{tabular}

Obtained $x^{2}=7.47$ with $12 \mathrm{df}$.

Critical $x^{2}=21.03 \quad$ p $>.05$ 
TABLE 25

MOST EFFECTIVE MANNER TO LEARN

VALUES AND SEX

\begin{tabular}{lccr}
\hline & Male & Female & Total \\
\hline $\begin{array}{l}\text { Reward and } \\
\text { Punishment }\end{array}$ & 10 & 21 & 31 \\
$\begin{array}{l}\text { Example and } \\
\text { Model }\end{array}$ & 35 & 41 & 76 \\
$\begin{array}{l}\text { Realizing } \\
\text { Consequences }\end{array}$ & 33 & 31 & 64 \\
$\begin{array}{l}\text { Other } \\
\text { Total }\end{array}$ & 6 & 6 & 12 \\
\hline
\end{tabular}

Obtained $\chi^{2}=3.23$ with $3 \mathrm{df}$.

Critical $x^{2}=7.82 \quad \mathrm{p}>.05$

TABLE 26

MOST EFFECTIVE MANNER TO LEARN VALUES AND AGE

\begin{tabular}{lcccccc}
\hline \hline & $17-18$ & $19-20$ & $21-22$ & $23-24$ & $25+$ & Total \\
\hline $\begin{array}{l}\text { Reward and } \\
\text { Punishment }\end{array}$ & 6 & 11 & 9 & 2 & 3 & 31 \\
$\begin{array}{l}\text { Example and } \\
\text { Model }\end{array}$ & 10 & 21 & 22 & 3 & 20 & 76 \\
$\begin{array}{l}\text { Realizing } \\
\text { Consequences }\end{array}$ & 6 & 28 & 17 & 6 & 7 & 64 \\
$\begin{array}{l}\text { Other } \\
\text { Total }\end{array}$ & 1 & 4 & 3 & 1 & 3 & 12 \\
\hline
\end{tabular}

Obtained $\chi^{2}=8.91$ with $12 \mathrm{df}$.

Critical $\chi^{2}=21.03$

$\mathrm{p}>.05$ 
TABLE 27

MOST EFFECTIVE MANNER TO LEARN VALUES AND RACE

\begin{tabular}{lccccc}
\hline & White & Black & Oriental & Other & Total \\
\hline $\begin{array}{l}\text { Reward and } \\
\text { Punishment }\end{array}$ & 22 & 7 & 1 & 1 & 31 \\
$\begin{array}{l}\text { Example and } \\
\text { Model }\end{array}$ & 62 & 10 & 4 & 0 & 76 \\
$\begin{array}{l}\text { Realizing } \\
\text { Consequences }\end{array}$ & 56 & 5 & 2 & 1 & 64 \\
$\begin{array}{l}\text { Other } \\
\text { Total }\end{array}$ & 11 & 1 & 0 & 0 & 12 \\
\hline
\end{tabular}

Obtained $\chi^{2}=4.60$ with $9 \mathrm{df}$.

Critical $x^{2}=16.92 \quad \mathrm{p}>.05$

TABLE 28

MOST EFFECTIVE MANNER TO LEARN VALUES AND RESIDENCE

\begin{tabular}{|c|c|c|c|c|c|c|}
\hline & Farm & $\begin{array}{r}\text { Under } \\
25,000\end{array}$ & $\begin{array}{l}25,000 \\
50,000\end{array}$ & $\begin{array}{c}50,000- \\
100,000\end{array}$ & $\begin{array}{c}\text { Over } \\
100,000\end{array}$ & Total \\
\hline Reward and & & & & . & & \\
\hline Punishment & 6 & 9 & 7 & 3 & 6 & 31 \\
\hline Example and & & & & & & \\
\hline Mode1 & 28 & 17 & 11 & 12 & 8 & 76 \\
\hline Realizing & & & & & & \\
\hline Consequences & 17 & 18 & 7 & 13 & 9 & 64 \\
\hline Other & 4 & 2 & 4 & 0 & 2 & 12 \\
\hline Total & 55 & 46 & 29 & 28 & 25 & 183 \\
\hline
\end{tabular}

Obtained $x^{2}=7.23$ with $12 \mathrm{df}$.

Critical $\chi^{2}=21.03 \quad \mathrm{p}>.05$ 
TABLE 29

MOST EFFECTIVE MANNER TO LEARN VALUES AND FAMILY RELATIONS COURSE

\begin{tabular}{lccc}
\hline & Yes & No & Tota1 \\
\hline $\begin{array}{l}\text { Reward and } \\
\text { Punishment }\end{array}$ & 14 & 17 & 31 \\
$\begin{array}{l}\text { Example and } \\
\text { Mode1 }\end{array}$ & 34 & 42 & 76 \\
$\begin{array}{l}\text { Realizing } \\
\text { Consequences }\end{array}$ & 25 & 39 & 64 \\
Other & 6 & 6 & 12 \\
\hline Total & 79 & 104 & 183 \\
\hline
\end{tabular}

Obtained $x^{2}=0.79$ with $3 \mathrm{df}$. Critical $\chi^{2}=7.82 \quad \mathrm{p}>.05$

TABLE 30

MOST EFFECTIVE MANNER TO LEARN VALUES AND TYPE OF DISCIPLINE

\begin{tabular}{|c|c|c|c|c|c|c|c|c|c|c|}
\hline & \multirow{2}{*}{$\begin{array}{l}\text { Very } \\
1\end{array}$} & \multicolumn{3}{|c|}{ Permissive } & \multirow[b]{2}{*}{5} & \multirow[b]{2}{*}{6} & \multicolumn{3}{|c|}{ Very Strict } & \multirow[b]{2}{*}{ Total } \\
\hline & & 2 & 3 & 4 & & & 7 & 8 & 9 & \\
\hline \multirow{2}{*}{\multicolumn{11}{|c|}{ Reward and }} \\
\hline & & & & & & & & & & \\
\hline Punishment & 0 & 0 & 0 & 3 & 7 & 3 & 10 & 8 & 0 & 31 \\
\hline \multicolumn{11}{|l|}{ Example and } \\
\hline Model & 0 & 1 & 0 & 2 & 20 & 13 & 28 & 10 & 2 & 76 \\
\hline \multicolumn{11}{|l|}{ Realizing } \\
\hline Consequences & 0 & 0 & 2 & 6 & 13 & 9 & 24 & 8 & 1 & 63 \\
\hline Other & 0 & 0 & 0 & 0 & 4 & 2 & 3 & 3 & 0 & 12 \\
\hline Total & 0 & 1 & 2 & 11 & 44 & 27 & 65 & 29 & 3 & 182 \\
\hline
\end{tabular}

Obtained $\chi^{2}=6.83$ with $24 \mathrm{df}$.

Critical $\chi^{2}=36.42$

$\mathrm{p}>.05$ 
TABLE 31

MOST EFFECTIVE MANNER TO LEARN VALUES AND

RELATIONSHIP WITH PARENTS

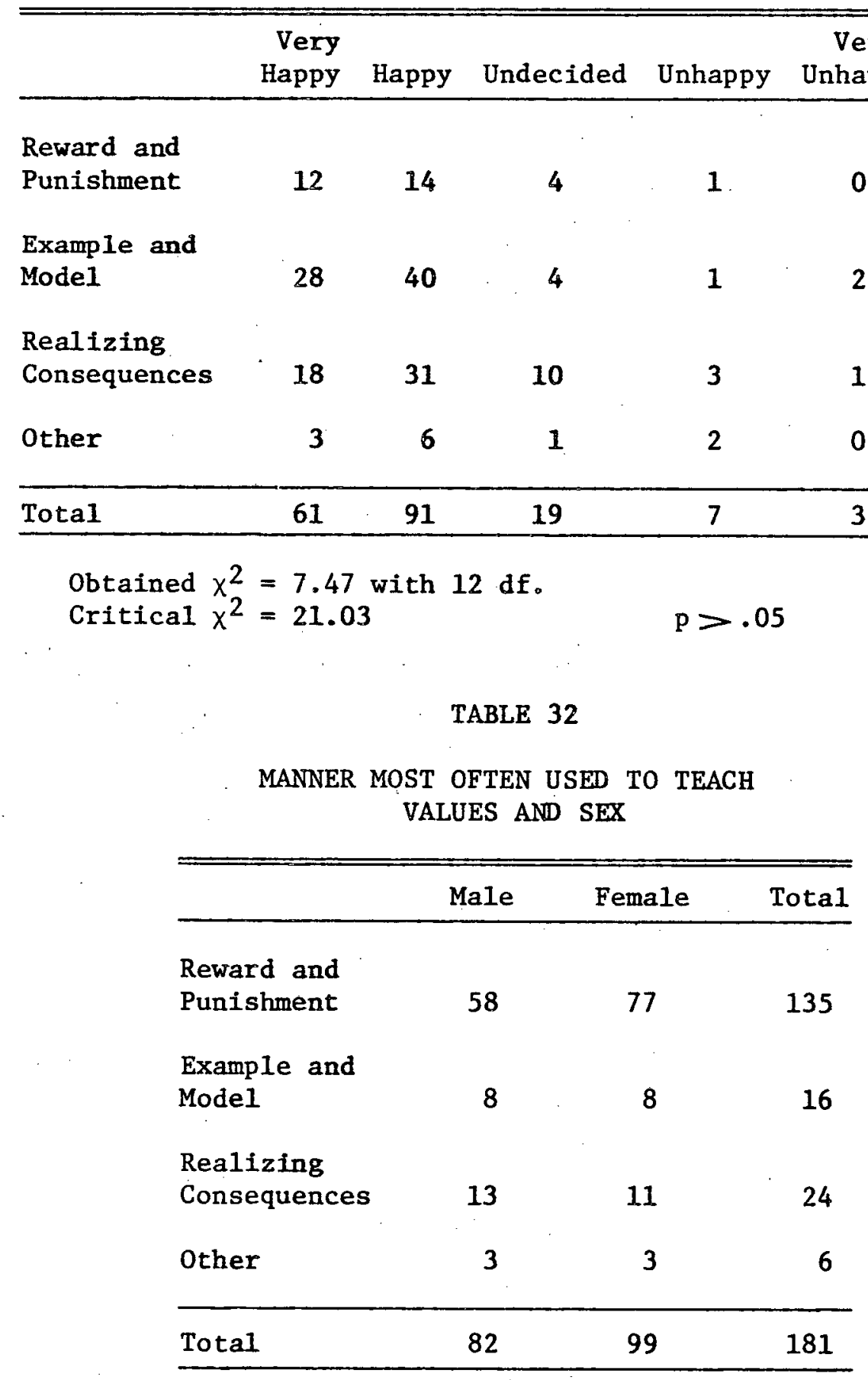

Obtained $x^{2}=0.70$ with $3 \mathrm{df}$.

Critical $\chi^{2}=7.82 \quad \mathrm{p}>.05$ 
TABLE 33

MANNER MOST OFTEN USED TO TEACH VALUES AND AGE

\begin{tabular}{lcccccc}
\hline & $17-18$ & $19-20$ & $21-22$ & $23-24$ & $25+$ & Total \\
\hline $\begin{array}{l}\text { Reward and } \\
\text { Punishment }\end{array}$ & 16 & 47 & 40 & 8 & 24 & 135 \\
$\begin{array}{l}\text { Example and } \\
\text { Model }\end{array}$ & 1 & 5 & 3 & 2 & 5 & 16 \\
$\begin{array}{l}\text { Realizing } \\
\text { Consequences }\end{array}$ & 3 & 11 & 7 & 2 & 1 & 24 \\
$\begin{array}{l}\text { Other } \\
\text { Total }\end{array}$ & 2 & 1 & 1 & 0 & 2 & 6 \\
\hline
\end{tabular}

Obtained $x^{2}=5.14$ with $12 \mathrm{df}$. Critical $x^{2}=21.03 \quad p>.05$

TABLE 34

MANNER MOST OFTEN USED TO TEACH VALUES AND RACE

\begin{tabular}{lccccc}
\hline & White & Black & Oriental & Other & Total \\
\hline $\begin{array}{l}\text { Reward and } \\
\text { Punishment }\end{array}$ & 110 & 17 & 6 & 2 & 135 \\
$\begin{array}{l}\text { Example and } \\
\text { Model }\end{array}$ & 13 & 2 & 1 & 0 & 16 \\
$\begin{array}{l}\text { Realizing } \\
\text { Consequences }\end{array}$ & 22 & 2 & 0 & 0 & 24 \\
$\begin{array}{l}\text { Other } \\
\text { Total }\end{array}$ & 5 & 1 & 0 & 0 & 6 \\
\hline
\end{tabular}

Obtained $x^{2}=4.61$ with $9 \mathrm{df}$. Critical $\chi^{2}=16.92 \quad \mathrm{p}>.05$ 
TABLE 35

MANNER MOST OFTEN USED TO TEACH VALUES

AND MOTHER EMPLOYMENT

\begin{tabular}{|c|c|c|c|c|}
\hline & No & Part Time & Ful1 Time & Total \\
\hline Reward and & & & & \\
\hline Punishment & 84 & 31 & 20 & 135 \\
\hline \multicolumn{5}{|l|}{ Example and } \\
\hline Mode1 & 12 & 1 & 3 & 16 \\
\hline Realizing & & & & \\
\hline Consequences & 15 & 6 & 3 & 24 \\
\hline Other & 4 & 2 & 0 & 6 \\
\hline Total & 115 & 40 & 26 & 181 \\
\hline
\end{tabular}

Obtained $x^{2}=1.61$ with $6 \mathrm{df}$.

Critical $\chi^{2}=12.59 \quad \mathrm{p}>.05$

TABLE 36

MANNER MOST OFTEN USED TO TEACH VALUES AND RESIDENCE

\begin{tabular}{lcccccc}
\hline & Farm & $\begin{array}{r}\text { Under } \\
25,000\end{array}$ & $\begin{array}{c}25,000- \\
50,000\end{array}$ & $\begin{array}{r}50,000- \\
100,000\end{array}$ & $\begin{array}{c}\text { Over } \\
100,000\end{array}$ & Total \\
\hline $\begin{array}{l}\text { Reward and } \\
\text { Punishment }\end{array}$ & 44 & 35 & 20 & 22 & 14 & 135 \\
$\begin{array}{l}\text { Example and } \\
\text { Model }\end{array}$ & 5 & 2 & 3 & 1 & 5 & 16 \\
$\begin{array}{l}\text { Realizing } \\
\text { Consequences }\end{array}$ & 5 & 6 & 6 & 2 & 5 & 24 \\
Other & 1 & 2 & 0 & 2 & 1 & 6 \\
\hline Total & 55 & 45 & 29 & 27 & 25 & 181 \\
\hline
\end{tabular}

obtained $x^{2}=7.13$ with $12 \mathrm{df}$.

Critical $x^{2}=21.03 \quad p>.05$ 
TABLE 37

MANNER MOST OFTEN USED TO TEACH VALUES AND

SOCIO-ECONOMIC STATUS

\begin{tabular}{lcccccc}
\hline & Upper & $\begin{array}{r}\text { Upper } \\
\text { Middle }\end{array}$ & $\begin{array}{r}\text { Lower } \\
\text { Middle }\end{array}$ & $\begin{array}{r}\text { Upper } \\
\text { Lower }\end{array}$ & $\begin{array}{r}\text { Lower } \\
\text { Lower }\end{array}$ & Total \\
\hline $\begin{array}{l}\text { Reward and } \\
\text { Punishment }\end{array}$ & 9 & 58 & 35 & 26 & 1 & 129 \\
$\begin{array}{l}\text { Example and } \\
\text { Model }\end{array}$ & 2 & 3 & 6 & 1 & 1 & 13 \\
$\begin{array}{l}\text { Realizing } \\
\text { Consequences }\end{array}$ & 4 & 4 & 10 & 3 & 1 & 22 \\
$\begin{array}{l}\text { Other } \\
\text { Total }\end{array}$ & 0 & 3 & 1 & 2 & 0 & 6 \\
\hline
\end{tabular}

Obtained $x_{2}^{2}=8.56$ with $12 \mathrm{df}$.

Critical $\chi^{2}=21.03 \quad \mathrm{p}>.05$

TABLE 38

MANNER MOST OFTEN USED TO TEACH VALUES AND TYPE OF DISCIPLINE

\begin{tabular}{|c|c|c|c|c|c|c|c|c|c|c|}
\hline & $\begin{array}{l}\text { Very } \\
1\end{array}$ & $\begin{array}{l}\mathrm{Pe} \\
2\end{array}$ & $\begin{array}{c}\text { iss } \\
3\end{array}$ & $\begin{array}{l}\text { ve } \\
4\end{array}$ & 5 & 6 & $\begin{array}{c}\text { Ver } \\
7\end{array}$ & $\begin{array}{c}\text { Str } \\
8\end{array}$ & t & Total \\
\hline Reward and & & : & & & & & & & & \\
\hline Punishment & 0 & 1 & 2 & 7 & 32 & 21 & 48 & 22 & 2 & 135 \\
\hline \multicolumn{11}{|l|}{ Example and } \\
\hline Mode1 & 0 & 0 & 0 & 1 & 4 & 4 & 4 & 2 & 1 & 16 \\
\hline \multicolumn{11}{|l|}{ Realizing } \\
\hline Consequences & 0 & 0 & 0 & 2 & 8 & 1 & 8 & 4 & 0 & 23 \\
\hline Other & 0 & 0 & 0 & 1 & 0 & 1. & 4 & 0 & 0 & 6 \\
\hline Total & 0 & 1 & 2 & 11 & 44 & 27 & 64 & 28 & 3 & 180 \\
\hline
\end{tabular}

Obtained $x^{2}=5.54$ with $24 \mathrm{df}$.

Critical $x^{2}=36.42 \quad p>.05$ 
TABLE 39

MANNER MOST OFTEN USED TO TEACH VALUES AND RELATIONSHIP WITH PARENTS

\begin{tabular}{lcccccc}
\hline & $\begin{array}{c}\text { Very } \\
\text { Happy }\end{array}$ & Happy & Undecided & Unhappy & $\begin{array}{c}\text { Very } \\
\text { Unhappy }\end{array}$ & Total \\
\hline $\begin{array}{l}\text { Reward and } \\
\text { Punishment }\end{array}$ & 45 & 70 & 15 & 4 & 1 & 135 \\
$\begin{array}{l}\text { Example and } \\
\text { Mode1 }\end{array}$ & 5 & 8 & 0 & 1 & 1 & 15 \\
$\begin{array}{l}\text { Realizing } \\
\text { Consequences }\end{array}$ & 10 & 8 & 4 & 0 & 1 & 23 \\
Other & 1 & 3 & 0 & 2 & 0 & 6 \\
\hline $\begin{array}{l}\text { Total } \\
\text { Ther }\end{array}$ & 61 & 89 & 19 & 7 & 3 & 179 \\
\hline
\end{tabular}

Obtained $\chi^{2}=11.94$ with $12 \mathrm{df}$.

Critical $\chi^{2}=21.03 \quad \mathrm{p}>.05$

(f) marital status of parents, (g) socio-economic class, and (h) happiness of childhood relationship with parents. Each of these eight sub-hypotheses was supported.

Hypothesis 3

There is no significant difference in perceptions concerning the most effective manner in which the values involved in character development are learned when respondents are classified according to (a) sex, (b) age, (c) race, (d) residence, (e) exposure to a family relations course, (f) prevailing type of discipline in family of orientation, and (g) happiness of childhood relationship with parents. Each of these seven sub-hypotheses was supported. 
Hypothesis 4

There is no significant difference in perceptions concerning the manner in which parents most often help children learn values involved in character development when respondents are classified according to (a) sex, (b) age, (c) race, (d) employment status of mother, (e) residence, (f) socio-economic status, (g) prevailing type of discipline in family of orientation, and (h) happiness of childhood relationship with parents. Each of these eight subhypotheses was supported. 


\section{CHAPTER V}

\section{DISCUSSION OF FINDINGS}

\section{Introduction}

Selected perceptions concerning character development and values important to the development of positive character development are discussed in this chapter. The perceptions are examined according to total group responses and according to sex. Questionnaire responses from the Kreps (1970) study are listed at the beginning of each subheading and, where applicable, commented upon in relation to this study's results.

\section{Perceptions of the Most Important Values for Parents to Assist Children in Learning in Order to Promote Positive Character Development}

As illustrated in Table 2, the five values which had the highest rate of selection as values most important for parents to assist children in learning are as follows: Spiritual Development, Honesty and Integrity, Seeing Each Person as Having Dignity and Worth, Self-Discipline, and Moral Courage.

Respondents in the Kreps (1970) study selected the values of Honesty and Integrity, Spiritual Development, Seeing Each Person as Having Dignity and Worth, Self-Respect, and Moral Courage as the values most. important for parents to assist children in learning. The first two values having the highest rate of selection (Honesty 
and Integrity and Spiritual Development) are reversed in Kreps' study from the present study.

Except for Spiritual Development, these results are similar to the research of others (Hartshorne \& May, 1928, Havighurst \& Taba, 1949; Mitche11, 1943; Peck \& Havighurst, 1960; Thompson, 1949 , 1952). All other studies reviewed listed the value of Honesty as the first most important value in character development. Kohlberg (1964, pp. 385, 386) wrote that for Hartshorne and May (1928), character traits included honesty, service, and self-control (Persistence in assigned tasks).

Havighurst and Taba (1949, pp. 4, 5, 8, 48, 49) selected five traits as representative of the traits which make up moral character. In descending order of relationship importance, the traits are: honesty, loyalty, responsibility, moral courage, and friendliness.

Peck and Havighurst (1960) considered the moral scores of honesty, responsibility, loyalty, courage, and friendliness as the basic components of character. Mitchell (1943) and Thompson (1949, 1952), in their research of values, reported honesty having the highest rank.

\section{Spiritual Development}

Spiritual Development was ranked by these respondents as the most important value to learn. Why? Ninety-four per cent of the subjects were Protestants; 86.5 per cent specified their religious preference as SDA. A possible explanation for the choice of spiritual development ranking highest may be that SDA religious training, 
knowledge, and education influenced the ranking on this table. White (1903a) wrote that "Higher than the highest human thought can reach is God's ideal for His children. Godliness--Godlikeness-is the goal to be reached (p. 18)." Implicit in this statement is the ideal of spiritual development. Statements which refer to this high cal1ing are to be found in her writings (1948e, pp.148, 152).

\section{Honesty and Integrity}

Honesty and Integrity are similarly endorsed by White. She states (1903a) that "The greatest want of the world is the want of menmen - . who in their inmost souls are true and honest, . (p. 57)." She (1948d) refers to the 'golden rule' as "the true rule of honesty (p. 359)." She (1948f) writes that "Life's best things [are] . . honesty .. . unsullied integrity . . (p. 27)" and (1903b) "truthfulness and integrity are attributes of God."

Seeing Each Person as Having Dignity and Worth

Selection of this value may reflect the teaching of White. She (1923) wrote:

It were better not to live than to exist day by day devoid of that love which Christ has revealed in His Character, and has enjoined upon His children. Said Christ, "Love one another as I have loved you." We live in a hard, unfeeling, uncharitable world. Satan and his confederacy are plying every art to seduce the souls for whom Christ has given His precious life. Every one who loves God in sincerity and truth, will love the souls for whom Christ has died. If we wish to do good to souls, our success with these souls will be in proportion to their belief in our belief in, and appreciation of them (pp. 280, 281).

Other statements (1888, p. 205, 1890, p. 579, 1903a, pp. 240, 241, 1905, pp. $165,166,361,1917$, p. 237) are found in her writings related to this value. 


\section{Self-Discipline}

This value, also referred to as self-control, is necessary for the development of other positive values. The selection of this value may be due to the doctrinal emphasis SDAs put on discipline and self-control (Theobald, 1974, p. 127). White (1930) states that "The highest evidence of nobility in a Christian is self-control (p. 134)." This noble character

- . is not the result of accident; it is not due to special favors or endowments of Providence. A noble character is the result of self-discipline, of the subjection of the lower to the higher nature--the surrender of self for the service of love to God and man (White, 1903a, p. 57).

Another statement written by White (1898a, p. 101) is that self-control should be acquired in childhood and youth when the character is most impressible.

\section{Moral Courage}

Moral Courage, the fifth most important value chosen by respondents to be learned may reflect the teaching of White (1903a) when she wrote:

The greatest want of the world is the want of men--men who will not be bought or sold, men who in their inmost souls are true and honest, men who do not fear to call sin by its right name, men whose conscience is as true to duty as the needle to the pole, men who will stand for the right though the heavens fall (p. 57).

Two other quotations from White that help to define the qualities

implicit in moral courage as well as point out the importance of its development in the life are:

Men, women, and youth, God requires you to possess moral courage, steadiness of purpose, fortitude and perseverance, minds that cannot take the assertions of another, but which will investigate for themselves before receiving or rejecting, that will study and weight evidence, and take it to the Lord in prayer $(1948 \mathrm{~b}, \mathrm{p} .130)$. 
There is no work more important than the education of our youth. - . They should be trained to have courage to resist the tide of moral poilution in this degenerate age (1943, p. 46). Ligon (1956) wrote that ". . . moral dependability is certainly a mark of strong character (p. 275)."

\section{Comparison of Subjects}

As shown in Table 2, a higher percentage of female subjects than male chose the first three values (Spiritual Development, Honesty and Integrity, Seeing Each Person as Having Dignity and Worth); a higher percentage of males than females chose values four and five (Self-Discipline and Moral Courage). Various studies suggest that sex exerts an influence on the values people hold.

The work of Schuster (1968, p. 92) and Rowland and DelCampo (1968, p. 88) shows distinct differences between male and female subjects: male boys rated higher than female girls on theoretical, political and economic values; female girls attached more importance on social, aesthetic and religious values. In Moss (1955, p. 42) a work Parilla (1971, p. 8) reviewed, it was found that girls placed greater importance on kindness and consideration for feelings of other people than boys.

\section{Perceptions of Values Which Parents are Most Successful in Helping Children Learn}

As illustrated in Table 3, values which had the highest rate of selection as values parents are most successful in helping children learn are Self-Reliance, Determination, and Intellectual Inquisitiveness.

Kreps (1970) listed the values of Honesty and Integrity, Friendliness, and Self-Reliance as the values most frequently selected 
by the respondents as values parents are most successful in helping children learn.

Self-Reliance

Referring to Self-Reliance, Kreps (1971) wrote that

The frequentl selection of self-reliance as a value parents are successful in helping children learn may be due, in part, to the influence that the mass media has had upon parents. Child development specialists have stressed the importance of the development of this value in their books in childrearing and in popular magazine articles (p. 35).

Perhaps another reason why respondents chose this value most frequently is the SDA doctrinal emphasis on self-reliance. White (1923) wrote that "So far as possible, every child should be trained to selfreliance . . that . . a well-balanced, harmonious character may be formed (p. 57)." She (1948c) said that children left to depend upon their own resources "frequently develop characters of industry, frugality, and moral worth, which lie at the foundation of success in the Christian life (pp. 122, 123)."

White (1954, p. 157) declares that youth should be taught that this world is a battle field and life a battle. As such, many of her statements reflect how self-reliance develops. Illustrations are:

It is obstacles that make men strong. It is not helps, but difficulties, conflicts, rebuffs, that make men of moral sinew. Too much ease and avoiding responsibility have made weaklings and dwarfs of those who ought to be responsible men of moral power and strong spiritual muscle (1948c, p. 495).

Beyond the discipline of the home and the school, all have to meet the stern discipline of life... Let them [ the children and youth] be taught that the true test of character is found in the willingness to bear burdens, to take the hard place, to do the work that needs to be done, through it brings no earthly recognition or reward (1903a, p. 295). 
It is not a great work and great battles alone which try the soul and demand courage. Everyday life brings its perplexities, trials, and discouragements. It is the humble work which frequently draws upon the patience and the fortitude. Selfreliance and resolution will be necessary to meet and conquer all difficulties (1948c, p. 81).

Forced to depend upon their own resources, they [the great majority of the best and noblest men of all ages--Abraham, Jacob, Joseph, Moses, David, and Elisha] learned to combat difficulties and to surmount obstacles, and they gained courage and perseverance. They learned the lessons of self-reliance and self-control. . . . When called to their 'lifework, they brought to it physical and mental power, buoyance of spirit, ability to plan and execute, and steadfastness in resisting evil, that make them a positive power for good in the world (1905, p. 366).

Ninety students $(48.6 \%)$ chose Self-Reliance as a value parents are successful in helping their children learn. Havighurst and Taba (1949, p. 32) state that this is a value which the upper-middle class instill in their children. Other studies on social class and values affirm self-reliance as a middle-class value.

Determination

Determination is similarly endorsed by White as a value important for success in life. She wrote:

True Christian character should be marked by firmness of purpose, an indomitable determination, which cannot be molded or subdued by earth or hell (1948d, pp. 543, 544).

Remember that you will never reach a higher standard than you yourself set. - . Opposing circumstances should create a firm determination to overcome them. The breaking down of one barrier will give greater ability and courage to go forward. Press with determination in the right direction, and circumstances will be your helpers, not your hindrances (1900, pp. 331,332 ).

Intellectual Inquisitiveness

Inte1lectual Inquisitiveness is the third most important value which subjects perceive parents as successful in helping children learn. 
This selection may be related to SDA teachings, the work of the SDA church, and the growth of Adventism. In order to clarify this possibility, this section is developed in four subheadings. They are:

(a) Cultivating the Intellect, (b) Education and the Church, (c)

Review of the Literature, and (d) Conclusions.

Cultivating the Intellect. In several of her works, White states that "cultivated intellect is a great treasure (1948c, p. 539)." "Mental culture is what we as a people need, and what we must have in order to meet the demands of the time (1948d, p. 414)," "God requires the training of the mental faculties (1900, p. 333)," "We are to show a superiority in intellect, in understanding, in skill and knowledge (1900, p. 358)," God "designs that His servants shall possess more intelligence and clearer discernment than the worldling (1900, p. 333)," "A11 intellectual laziness is sin (1948d, p. 399)," the intellect should be cultivated (1948c, p. 26, 1948d, p. 399), and it is a duty to cultivate and to exercise the intellect $(1905$, p. $398,1943, \mathrm{p}$. 541, 1948d, P. 563).

Because the Lord bids us to love Him with all the heart, soul, strength, and mind, we are under obligation to develop the intellect to its fullest capacity, wrote White (1900, p. 333). She (1948d) declares that Christians are to

Exercise the mental powers, . . Let not intellectual slothfulness close up your path to greater knowledge. Learn to reflect as well as to study, that your minds may expand, strengthen, and develop. Never think that you have learned enough and that you may now relax your efforts. The cultivated mind is the measure of the man. Your education should continue during your lifetime; every day you should be learning and putting to practical use the knowledge gained ( $p$. 561). 
Education and the Church. Ellen White wrote extensively on the subject of education and church and viewed the total scope of education to be the concern of the whole church. Today, the church's concern is reflected in its support to Adventist education. Oosterwal (1972, pp. 55, 58) wrote that Adventists have invested over a billion dollars in buildings and equipment . . forty per cent of this amount has been invested in church buildings and educational institutions. In the 1970 Total Denominational Investment Report of $\$ 1,311,417,548.58$, North American educational institutions received 20.0 per cent of the total investment. Allen (1972, p. 3) noted that the two-millionmember denomination in North America operates two universities, 11 colleges, 83 secondary academies, and 9.11 elementary schools. One observation made by Salisbury $(1964, \mathrm{pp} .360,395)$ is that the Lutheran Church--Missouri Synod--and the Seventh-day Adventists have made the greatest Protestant effort in parochial education. Another observation ( $p .162$ ) is that the Adventist effort to educate its youth is comparable to the Catholic school effort.

Oosterwal (1972) wrote that "Christ established His Church for a missionary purpose (p. 69)." According to Harder (Focus supplement No. 15, p. 4) three professions seem particularly necessary to carry on the church's mission: medicine, the ministry, and teaching. Oosterwal (1972, p. 514) noted that, in the United States, of a total SDA working force of some seventy thousand people, roughly 40 per cent work in Adventist schools for Adventist children, 30 per cent in medical work, 13 per cent in administrative positions, and 10 per cent in pastoral work. 
Review of the Literature. A review of the literature suggests that education is a major mechanism used by Adventists to carry out the church's mission and for social and occupational mobility. Golock and Stark (1965, p. 355) noted that sects have the tendency to socialize their members to higher economic status. Manning (1973, pp. 17, 18) states that the socio-economic profile of Barbadian Seventh-day Adventists is consonant with the Weberian argument (1958) that systematic, rational asceticism promotes social advancement.

Historically, SDAs at one time began as a sect (Butler, 1974, p. 200; Johnstone, 1975, p. 124) but have evolved to full-fledged denominational status in the United States today. Wilson (1970, Pp. 102, 103) regards them as an unusual sect combining several distinctive features which give them an appearance near to that of an institutionalized denomination. Butler (1974, p. 200) states that this shift from sect to denomination in Adventism involved inevitable cultural and political accommodations. Butler (1974) wrote that "Seventh-day Adventists embraced social and economic upward mobility with religious zeal (p. 200)." Wilson (1974, p. 236) noted that an important reason why Adventists have shown a tendency toward becoming denominationalized is as a result of their inheritance of a

separate, full-time ministry which has led to increased concern with professional training, differentiation of ministry and laity, and which has given the movement some impetus towards intellectual orientations (p. 236).

The report "Seventh-day Adventist Youth at the Mid-Century" (1951) stated:

Compared proportionately with the general American public [United States Bureau of the Census] three times as many American Adventists were college graduates, and one and one-half times as 
many had completed the high school grades. Twice as many of the general population, proportionately, had their education stopped at or below the eighth grade (p. 14).

Adventists were proportionately four times as numerous as the general population in the professional-technical group of occupations, and almost twice as numerous in the crafts and skilled trades ( $p .34$ ).

"A Study of Seventh-day Adventist Church Membership" (1961-62,

Report No. 2, p. 16, Figure 12) presents a comparison between the Pacific Union Conference of SDAs population and the general population (US Census). SDAs showed twice as many professional and technical workers (29.1\%) as the general population (14.3\%). Manning (1973) conducted field research in the anglophonic West Indies, primarily Barbados; where he states that "Adventism is the fastest growing reform movement in Christianity (p. 1)." He (p. 55) further notes that the church has the largest denominational school system, including 2 colleges, about 2 dozen secondary schools, and 50odd elementary schools.

Manning (1973, p. 18) compared Adventists ( $N=50$ males) to the general male population of Barbados (1970 census) and produced this data: (a) Fifty-four per cent of the Adventist subjects were secondary school graduates as compared to 15 per cent of the male working class. (b) A higher percentage of Adventists (75\%) were either self-employed or held professional or white collar positions as compared to the general male population (55\%). (c) The majority of SDA subjects (75\%) 1ived in stone bungalows, one of the primary indicators of middle-class standing in West Indian society.

Schwartz (1970, pp. 126, 200, 201, 210), interviewing a limited sample of SDAs state that Adventist desire and expect upward 
occupational mobility for either their children or themselves and achieve it. Manning (1973, pp。18, 19) observed a pattern of upward socio-economic movement in his subjects: Adventists were recruited primarily from the lower and lower middle classes, had usually achieved middle class standing in one generation, and within two generations had, through acquiring university degrees and securing professional positions, broken into the upper-middle class. Research (Manning, 1973, pp. 14, 19; Schwartz, 1970, pp. 126, 135, 189) indicates that Adventists place a high evaluation on education, especially professional, managerial, and businessman occupations which allows for Sabbath observance. Theobald (1974) wrote that SDAs have been described as "the intellectuals of fundamentalism (p. 126)." Other observations of the value Adventists place on the intellect could be made: intellectual imagery prevades the worship service (Manning, 1973, p. 11; Salisbury, 1964, p. 163; Schwartz, 1970, p. 138; Spence, 1957, pp. 56, 59) and there is an intellectual content in the church's ethics and prophecy (Manning, 1973, pp. 10, 11; Spence, 1957, p. 55).

Conclusion. It could be concluded that intellectual inquisitiveness, the third most important value which subjects perceive parents as helping their children learn, is bound up in (a) the church's history of evolution from sect to denomination, (b) the church's worship services, ethnics, and prophecy, and (c) the propogated doctrine of the church which is supported by an educational program, all of which leaves its impress upon the parents who then "teach" it as an important character value to possess to their children. 
Comparison of Subjects

As shown in Table 3, a higher percentage of male subjects chose the values of Self-Reliance and Intellectual Inquisitiveness than female subjects. Parilla (1971), reviewing the study of Mussen, Conger and Kagan (1956, p. 580) wrote that they declare that boys generally places more emphasis on the ability to solve problems, intellectual competence and the mastery of skills, while girls are primarily concerned with maintaining friendly relations with others (pp. 8,9).

In explaining these differences, Parilla (1971) wrote:

These differences are understandable. They are forged by our culture. Boys are expected to be independent, selfsufficient and concerned with mastery of problems. Girls, on the other hand, are expected to be more dependent and submissive (p. 9).

\section{Perceptions of Values Which Parents Most Often} Fail to Help Children Learn

As shown in Table 4, the three values which had the highest rate of selection as values parents most often fail to help children learn are Spiritual Development, Self-Discipline, and Seeing Each Person as Having Dignity and Worth.

Respondents in the Kreps (1970) study selected the values of Spiritual Development, Genuine Concern for and Responsibility for Others, and Moral Courage most frequently as the values that parents most often fail to help children learn. Both groups of subjects selected Spiritual Development most frequently.

Spiritual Development

Adventists view man as a unity of body, mind, and spirit. Each part of this 3-fold nature is developed by exercise. The 
spiritual nature is developed chiefly by religious instruction, with the Bible as the home text book and guide (White, 1954, pp. 505, 506, 508-510, 513). Spiritual Development was ranked by subjects as the value parents most often fail to help children learn. White (1954, pp. 182, 498) wrote that parents may be stumbling blocks to their children when they do not cooperate with the means God has provided for the spiritual development of the family. She (1954) stated that "Evil sentiments, falling from the lips of injudicious parents, are the chief hindrance to genuine conversion among children ( $p$. 498)." She (1954) further maintains that a parental disregard for the Word of God, a "I don't care; I will have my own way" attitude is reflected in the children (p. 509). White's statements may reflect one reason why respondents chose this value as the least successfully taught. Another reason for this choice may be related to the results of Bienvenu's (1969) study. Kreps (1971) reviewed the study and wrote:

- . over 2000 adolescents were asked the question "What would you like most to have changed in your home life?" It was found that one of the three most frequently given answers was "more religion" in the home. The fact that organized religion does not have as active a role in the family of today as in the past may be partially responsible for the finding that spiritual development was most often selected as the value parents were least successful in helping children learn (p. 38).

\section{Self-Discipline}

The frequent selection of Self-Discipline (11.4\%) as a value parents often fail to help children learn may be related to the findings of Table 8 . Here, ranked perceptions were that parents most of ten help children learn values involved in character development through 
(a) Reward and Punishment, (b) Realizing Consequences of Behavior,

and (c) Example and Model.

White (1903a) stated that "The object of discipline is the training of the child for self-government (p. 287)." It is reasonable to view self-discipline having as its foundation parental training and discipline. Improper training, adversive punishment, has negative results. White (1923) wrote

The severe training of youth, without properly directing them to think and act for themselves as their own capacity and turn of mind will allow, that by this means they may have growth of thought, feelings of self-respect, and confidence in their own ability to perform, will ever produce a class who are weak in mental and moral power. And when they stand in the world to act for themselves, they will reveal the fact that they are trained, like animals, and not educated. Their wills, instead of being guided, were forced into subjection by . . . harsh discipline . . (p. 17).

According to Havighurst (1962, pp. 433-436) reward and punishment in early moral training is directed toward control of the child's impulses. Later moral conscience is acquired through the process of identification with and imitation of family members and other persons with prestige and an emotional relationship to the child. As the child interacts with the community, reference groups whom the child views as having prestige and whom he identifies with further develops his character. Rational analysis and reflective thinking, the higher phases of thought development, are processes used in realizing consequences of behavior.

Hurlock (1967) presents related thoughts. She wrote: Without discipline, the adolescent will not develop the ego controls needed to help him adjust to the reality demands of life; with discipline, he will develop these controls and, as a result, make good adjustments to life's demands (p. 446). 
To play its role successfully, discipline must be adjusted to the developmental status of the individual . . (p.446).

older adolescents feel that their parents... should not use the same authoritarian approach used earlier, they want a more mature type of discipline, one that puts more stress in guidance than on prohibitions and punishments ( $p$. 446).

To summarize these statements on discipline, the manner used by the parents provide the foundation for the child's self-discipline. Reward and punishment, without the use of reason, results in a fixated immature level of conformity to mores and standards outside the person. The child who has been properly trained and disciplined with reward and punishment as well as with rational analysis and reflective thinking in realizing the consequences of behavior is better able to develop self-discipline and ego controls necessary to make good adjustment to life's demands.

The frequent selection of Self-Discipline as a value parents often fail to help children learn may be related to the statement of White (1903a) that "A noble character is the result of selfdiscipline. . (p. 57)." Respondents, interpreting themselves and those around them may see so few "noble characters" that the need of self-discipline in their own minds, next to spiritual development, is paramount.

\section{Seeing Each Person as Having Dignity and Worth}

The frequent selection of Seeing Each Person as Having Dignity and Worth as a value parents often fail to help children learn may be due, in part, to a study by Mitchell (1943, p. 111). He found that high school seniors, in ranking the importance of 13 virtues, gave the highest rank to honesty while the virtues of kindness, helpfulness, 
charity, and sympathy received lower rankings of $7,9,10$, and 12 respectively. Thompson (1962, pp. 534, 535), reporting a study he conducted in 1949, found subjects from grades six to twelve rated being honest as more praiseworthy than being kind.

White (1923, p. 280) wrote that "We live in a hard, unfeeling, uncharitable world" and that we are to love one another as Christ loves us. The selection of this value may be due, in part, to the respondents view of the general world at large--they perceive parents, in general, as not cultivating in themselves or their children this value as explained from these quotations by White:

Let each give love rather than exact it. Cultivate that which is noblest in yourselves, and be quick to recognize the good qualities in each other. The consciousness of being appreciated is a wonderful stimulus and satisfaction. Sympathy and respect encourage the striving after excellence, and love itself increases as it stimulates to nobler aims (1905, p. 361).

True polish, true politeness, is obtained only from a practical knowledge of the gospel of Christ. True politeness, true courtesy, is a kindness shown to all, high or low, rich or poor.

The essence of true politeness is consideration for others. The essential, enduring education is that which broadens the sympathies and encourages universal kindliness (1952, p. 423).

True courtesy is not learned by the mere practice of rules of etiquette. Propriety of deportment is at all times to be observed; whenever principle is not compromised, consideration of others will lead to compliance with accepted customs; but true courtesy requires no sacrifice of principle to conventionality. It ignores cast. It teaches self-respect, respect for the dignity of man as man, a regard for every member of the great human brotherhood (1903a, p. 240).

\section{Perceptions of Source of Greater Parental Influence of the Character Development of Children}

The majority of the subjects in Table 5 reported the Mother to be the more important parent in influencing the character development 
of children. This finding is supported by other research, including the Kreps (1970) study. Peck and Havighurst (1960, p. 180) found, on the basis of their sixteen year longitudinal study of character development, that the mother has a more profound and influential effect on character development than does the father. Agreeing with this position, Cole and $\operatorname{Hall}$ (1970, p. 388), Hurlock (1972, p. 434), and White $(1880,1948 \mathrm{~b}$, p. 536,1954, p. 24, 1958, p. 437) emphasize the importance of the mother's influence in early childhood development. Harris and Tseng (1957), in their study of attitudes of children in grades three through twelve, found both sexes more favorable to the mother than to the father. Bronfenbrenner (1961) found that adolescent sons and daughters reported mothers as the primary source of nurturance, affection, protectiveness, general discipline, material rewards and the making of decisions affecting the adolescent. The facts of these studies are compatible with the statements already cited.

\section{Perceptions of Source of Greatest Community Influence on Character Development}

The Family (Table 6) was selected by the majority of the respondents as the community influence that has the greatest influence on the child's character development. The subjects of Kreps (1970) study selected this community influence most often also. This finding coincides with the report of Ligon (1956) who stated that "The family is the fundamental social institution, on which all the others must depend (p. 140)." White (1954) agrees with this position and wrote that "Neither the church school nor the college affords the opportunities for establishing a child's character building upon the 
right foundation that are afforded in the home (p. 170)." Statements from other sources (Bradley \& Earp, 1966, pp. 55-58; Burroughs, 1968, p. 457; Havighurst \& Taba; 1949, p. 41; Ligon, 1956, p. 104; Mouly, 1968, p. 477; Pressey \& Kuhlen, 1957, p. 471) agree with this position. Most writers (Bradley \& Earp, 1966, p. 56; Peck \& Havighurst, 1960, pp. 123, 178-181, 183; Pressey \& Kuhlen, 1957, p. 464; Stone \& Church, 1957, p. 19; White, 1943, p. 142, 1948c, p. 144, 1952, p. 187, 1954, p. 170, etc.) noted the direct influence the parents have over their children. Effects of parental treatment persists in the individual as he grows older; he views the world and reacts to it as his parents viewed and acted toward him. Peck and Havighurst (1960) stated:

Character, as defined in this study, appears to be predominantly shaped by the intimate, emotionally powerful relationship between child and parents, within the family. Forces outside the family are not negligible nor irrelevant in their indirect effect on character formation, but it looks as though these forces operate mainly as they reinforce or reward child behavior that follows the socially approved parts of the parents behavior (p. 175).

The Peer Group received the next highest frequency count as an institution influencing character development. This finding is reflected in Hurlock's statement (1967, p. 119) that the child has three "social worlds" of the family, school, and neighborhood. These "social worlds" are expanded to include peer groups with which the adolescent identifies. Eventually, Hurlock maintains, the peer group becomes the adolescent's dominant social world. She depicts the movement of character influence to be from home to peer to community. 
Campbell (1964, p. 300) points out that peer influences increases as the child matures. Bronfenbrenner (1967, p. 61) states that there is a turning point at about the seventh grade where the child's peers have equal or greater influence in modeling, companionship, and guiding behavior.

Selection of responses in this study and the Kreps (1970) study are ranked the same. That is, the ranking by total selection is (a) Family, (b) Peers, (c) School, and (d) Church.

\section{Perceptions of the Most Effective Manner in Which Values Involved in Character Development are Learned}

Example and Models

Respondents, in Table 7, selected Example and Models as the most effective manner in. which values involved in character development are learned. Respondents in the Kreps (1970) study selected this manner most frequently also. This finding supports the statement of White (1948d) when she wrote that "Children should be taught be precept and example (p. 200)." Referring to the life of Jesus she (1903a) wrote: "What He taught, He 1ived. . . It was this that gave His teaching, power (pp. 78, 79)." Many other statements by White $(1903$, p. 150,1917, p. $384,1948 d$, p. 286) on the importance of example and model are to be found.

Realizing the Consequences of Behavior was also selected frequently as an effective manner in which values involved in character development are learned. This finding reflects the statement of White (1923) when she wrote that "The will must be trained to obey the dictates of reason and conscience (p. 57)." She also 
presented (1954, pp. 242, 243, 246, 252) the manner and method parents are to follow to encourage the reasoning powers of the child.

Reward and Punishment was chosen as the least effective manner in which values involved in character development are learned.

The ranking of Table 7 parallels the thinking of Jersild (1968). He wrote:

On the whole, it seems that a child is likely to be swayed by his parents' example if they use "psychological" rather than arbitrary methods. In the long run, reasoning or disapproval, through seeming withholding of affection, are likely to have more effect on a child's character than peremptory physical punishment ( $p$. 513).

Hurlock's findings (1972) are also compatible with this ranking.

She states:

The child can learn to behave in a socially approved manner throughout trial and error, through direct teaching, or through identification. of the three, direct teaching and identification are not only the best methods but also the most widely used. Trial-and-error learning is time-and energyconsuming, and the end result are often far from satisfactory (p. 377).

\section{Comparison of Subjects}

Examination of Table 7 shows a distinction in percentage frequencies between male and female respondents. Both groups are balanced in perceiving Example and Models as the most effective manner in which values involved in character development are learned. Males (39.3\%) endorsed Realizing the Consequences of Behavior, a reflective thinking process, more highly than females $(30.7 \%)$. In contrast females (20.8\%) endorsed Reward and Punishment more highly 
than males $(11.9 \%)$. This response may be reflected in the findings of Parilla (1971), who, reviewing various studies on sex differences and values held, reported males placing greater emphasis on the "ability to solve problems, intellectual competence and the master of skills," values which this culture instills in the male whereas females are "expected to be more dependent and submissive (pp. 8, 9)." Parilla's statements agree with this study's reported differences.

\section{Perceptions of the Manner Parents Most Often Use to Help Children Learn Values Involved in Character Development}

Reward and Punishment

As Table 8 indicates, Reward and Punishment was selected most frequently $(73.0 \%)$ as the manner in which parents most often use to help children learn values involved in character development. This manner was chosen most frequently by respondents in the Kreps (1970) study also. Realizing Consequences of Behavior received the second highest frequency of selection (13.0\%) and Example and Model received 8.6 per cent of the response. A possible explanation for these findings may be related to the work of Havighurst and Taba (1949, pp. 6, 7) who postulated that character, as a learned behavior, is learned through these three ways but ranked them (1) reward and punishment, (2) unconscious imitation, and (3) reflective thinking. Havighurst (1962) later wrote that there were four phases of moral development which follow in a sequence during the childhood years 1isted, they are:

1. Early moral training in the family, through reward and punishment. 
2. Identification with and imitation of persons with prestige and an emotional relationship to the child.

3. Learning morality from groups outside the family.

4. Rational analysis and reflective thinking (pp. 432-435)。

He believes that if a person is to become morally effective in . society, reasoning (reflective thinking) must actively and deliberately be cultivated; reflective thinking must be practiced and rewarded if it is to become a habit. Havighurst (1962) wrote that

Without the use of reason to guide behavior, moral development becomes fixated at the immature level of conformity to group mores or of obedience to a rigid irrational conscience (p. 436).

\section{Comparison of Subjects}

Male and female respondents of Table 8 endorse these values in a manner similar to the endorsements of Table 7 . It appears that the statements in the section Comparison of Subjects of Table 7 would apply here. 


\section{CHAPTER VI}

SUMMARY, RECOMMENDATIONS, AND CONCLUSIONS

\section{Summary}

The purpose of this study was to investigate the perceptions of college students on a Seventh-day Adventist campus concerning values involved in positive character development.

A 15 per cent sample, proportionally stratified by sex, was obtained in a random selection from the population in the College of Andrews University during Spring Quarter, 1974. Of the total 205 subjects composing the original sample, 185 subjects, representing a 90 per cent response, proportionally stratified by sex, returned the questionnaire used in this study. The respondents were predominantly white. Mast reported their mother not being employed for the major part of theix childhood. A listing of the largest percentages showed subjects to be seniors in college, in the age variable 19-20 years old, single, and in the upper middle socio-economic status level. A majority of the subjects were Protestants in background with a stated 86.5 per cent SDA. Over half of the subjects came from farms or towns under 25,000 in population. The Positive Character Values (PCV) List used in this study was developed by Kreps (1971) in order to obtain a list of values most often considered to promote positive character development and fulfill human living. The investigator used the PCV List as developed by 
Kreps but modified the background section of the questionnaire to conform to background characteristics of Andrews students.

A percentage and frequency count was used to analyze the respondent's perceptions concerning: (a) the five values perceived to be most important for parents to assist children in learning in order to promote positive character development, (b) the three values parents are most successful in helping children learn, (c) the three values which parents most often fail to help children learn, (d) the source of greater parental influence on the child's character development, (e) the source of greatest community influence on the child's character development, (f) the most effective manner in which values involved in character development are learned, and ( $g$ ) the manner which parents most often use to help chijdren learn values involved in character development.

The Chi-square test was used to examine the hypotheses in the study in order to determine if various perceptions concerning character development were significantly related to certain background factors. The major findings of the study were:

1. Spiritual Development, Honesty and Integrity, Seeing Each Person as Having Dignity and Worth, Self-Discipline, and Moral Courage were the five values selected as most important for parents to assist their children in learning in order to promote positive character development.

2. Self-Reliance, Determination, and Intellectual Inquisitiveness were most often selected as the three values parents are most successful in helping children learn. 
3. Spiritual Development, Self-Discipline, and Seeing Each Person as Having Dignity and Worth were most frequently selected as the three values parents most often fail to help children learn.

4. The Mother was selected more frequently as the source of greater parental influence on the child's character development.

5. The Family was selected most frequently as the source of greatest community influence on the child's character development.

6. Model and Example was most often selected as the most effective manner in which values involved in character development are learned.

7. Reward and Punishment was the most frequently selected manner which parents actually use to help children learn values involved in character development.

8. All of the non-directional null hypotheses were rejected at the probability leve1 of $\geqslant .05$.

\section{Recommendations}

Recommendations arising from the findings of this study are as follows:

1. Question 43 of the questionnaire might not have elicited the true opinion of the respondents in this study. Twenty-six of the twenty-seven subjects found it necessary to introduce a third answer, that is, "Both are equally important." Subsequent research with this questionnaire could perhaps include a third selection for respondents, 11

3. Both" or " 3. Other (Specify) - 
2. In addition to the above, another question could be introduced to ascertain that some values are better taught. by one specific sex parent.

3. Kreps (1970) "recommended that this investigation be duplicated in the future with a national sample of both high school and college students (p. 48)." It is further recommended that this investigation be duplicated with (a) a cross-culture intrafaith sample of Seventh-day Adventist college students and (b) a interfaith sample of college students attending their own church related school. Kreps (1970, p. 48) suggested that it would be beneficial in a national study to relate perceptions concerning character development to various childhood and personality variables.

\section{Conclusions}

Conclusions drawn from the findings of this study are as follows:

1. From the data of this study it would appear that Seventh-day Adventist philosophy influenced the perception rankings. The most outstanding illustration of this is the selection of "Spiritual Development" as the most important value children are to learn in order to promote positive character development. All other research on character value rankings reviewed, including the Kreps' (1970) study, ranked "Honesty" as most important.

2. Proportionally stratifying the subjects by sex produced a more meaningful study. Sex appears to exert an influence on the values subjects hold. The perception findings on sex differences concur with past studies reviewed. 
3. Analysis of data in the Kreps' (1970) study indicated a significant difference (significant at .001 level) in the chi-square analysis of greater parental influence when respondents were classified according to sex. This perhaps may be a function of biased (inappropriate) sampling procedure: subjects for her study were the students enrolled in the undergraduate course, Marriage 3142 , at Oklahoma State University in the spring semester of 1969. Results of this study, because of randomized sampling, are more precise (and do not agree with Kreps) in this regard. 
B I B L I O G R A P H Y 


\section{BIBLIOGRAPHY}

Ackerman, Nathan W. The Psychodynamics of Family Life. New York: Basic Books, 1958.

Allen, Jane. "100 Years of Adventist Church Schools." The Lake Union Herald 64 (April 11, 1972): 3.

Allport, Gordon W. Becoming. New Haven: Yale University Press, 1955.

"A Study of Seventh-day Adventist Church Membership." Reports 1 and 2. Pacific Union Conference of Seventh-day Adventist. Angwin, California: Pacific Union College Data Processing Laboratory. 1961-1962.

Bandura, A. and Walters, R. H. Adolescent Aggression. New York: Ronald Press, 1959.

Bienvenu, Millard J. "Why They Can't Talk to Us." The New York Times Magazine (May 14, 1969).

Bradley, R. C. and Earp, N. Wesley. "Development of Character in Our Youth." Social Studies 57 (February 1966): 55-58.

Bronfenbrenner, Urie. "Some Familial Antecedents of Responsibility and Leadership in Adolescents." In Leadership and InterPersona1 Behavior, pp. 239-271. Edited by L. Petrullo and B. M. Bass. New York: Holt, Rinehart and Wilson, Inc., 1961.

. "The Split-Level American Family." Saturday Review 50 (0ctober 7, 1967): 60-66.

Burroughs, J. A. "Character." The New Catholic Encyclopedia. 1967. Vol. 3.

Butler, Jonathan M. "Adventism and the American Experience." In The Rise of Adventism. Edited by Edwin S. Gaustad. Evanston, I11.: Harper and Row Publishers, 1974.

Calton, William R. From Animistic to Naturalistic Sociology. New York: McGraw-Hill, 1966. 
Campbe11, John D. "Peer Relations in Childhood." In Review of Child Development Research. Volume 2, pp. 289-322. Edited by Martin L. Hoffman and Lois Wladis Hoffman. New York: Russe11 Sage Foundation, 1964.

Christenson, James A. and Dillman, Don A. "Rural-Urban Value Patterns." Paper presented at the Rural Sociological Society Annual Meetings, College Park, Maryland, 23-26 August 1973. Bethesda, Md.: ERIC Document Reproduction Service, ED 078 995, 1973.

Clausen, John A. "Family Structure, Socialization, and Personality." In Review of Child Development Research. Volume 2, pp. 1-53. Edited by Lois Wladis Hoffman and Martin L. Hoffman. New York: Russe11 Sage Foundation, 1966.

Cole, Luella and Ha11, Irma Nelson. Psychology of Adolescence. 7th ed. New York: Holt, Rinehart and Wilson, Inc., 1970.

d'Arcy, Eric. Conscience and its Right to Freedom. 1961, Parts 1 and 2. Quoted by Ronald H. Preston. "Conscience." Dictionary of Christian Ethics. 1967.

Dillman, Don A. and Christenson, James A. "Value Orientations of Occupational Groups Toward Areas of Government Activities." Scientific paper No. 3941, Agriculture Research Center, Washington State University, Pullman, Washington, 1972.

Dupre, W., Callahan, E. R., and Williams, C. "Conscience." The New Catholic Encyclopedia. 1967. Vol. 4.

Eucken, Rudolf. "Character." Encyclopaedia of Religion and Ethics. 1931. Vol. 3.

Gabriel, John. Children Growing Up: the Development of Children's Personalities. 3rd ed. London: University of London Press Ltd., 1968.

Getzel, Jacob W. "The Acquisition of Values in School and Society." In The High School in a New Era, pp. 152-155. Edited by Francis S. Chase and Harold A. Anderson. Chicago: University of Chicago Press, 1958.

Golddiamond, Israel. "Moral Behavior: A Functional Analysis." Psychology Today 2 (September 1968): 31-34, 70.

Golock, Charles Y. and Stark, Rodney. Religion and Society in Tension. Chicago: Rand McNally and Company, 1965.

Grinder, R. "Parental Childrearing Practices, Conscience, and Resistance to Temptation of Sixth Grade Children." Child Development 33 (1962): 802-820. 
- "Relations Between Moral Judgment and Resistance to Temptation in Conscience Development." Paper read at meetings of the Society for Research in Child Development, Berkeley, Calif., April 1963.

Harder, Frederick E. J. "Adventist Higher Education." Focus Supplement No. 15: 1-8.

Harris, Dale B. and Tseng, Sing Chu. "Children's Attitudes Toward Peers and Parents as Revealed by Sentence Completions." Child Development 28 (December 1947): 401-411.

Hartshorne, H. and May, M. A. Studies in the Nature of Character: Vol. I, Studies in Deceit; Vol. II, Studies in Self-Control; Vo1. III, Studies in the Organization of Character. New York: Macmillan, 1928-1930.

Havighurst, Robert J. and Taba, Hilda. Adolescent Character and Personality. New York: John Wiley and Sons, Inc., 1949.

Havighurst, Robert J. Developmental Tasks and Education. 2nd ed. New York: David McKay Company, Inc., 1965.

- "How the Moral Life is Formed." Religious Education 57 (November-December 1962): 432-439.

Hendry, L. S. "Cognitive Processes in a Moral Conflict Situation." Unpublished doctoral dissertation, Yale University, 1960.

Hoffman, Martin L. "Childrearing Practices and Moral Development: Generalization from Empirical Research." Child Development 34 (June, 1963): 295-318.

Horn, M. J. The Second Skin. Boston: Houghton Mifflin Company, 1968.

Hurlock, Elizabeth. Adolescent Development. 3rd ed. New York: McGraw-Hi11, 1967 .

- Child Development. 5th ed. New York: McGraw-Hill Book Company, 1972.

Jersild, Arthur T. Child Psychology. 6th ed. Englewood Cliffs, N.J.: Prentice-Hall, Inc., 1968.

- The Psychology of Adolescence. 2nd ed. New York: Macmi11an Company, 1963.

Johnstone, Ronald L. Religion and Society in Interaction. Englewood Cliffs, New Jersey: Prentice-Hal1, Inc., 1975. 
Jones, Vernon. "Character Education." Encyclopedia of Educational Research. 1960.

Junell, Joseph S. "Can Our Schools Teach Moral Commitment?" Phi Delta Kappan 50 (April 1969): 447.

Kluckhohn, Clyde. "Value and Value-Orientations in the Theory of Action: An Exploration in Definition and Classification." In Toward a General Theory of Action, pp. 388-433. Edited by T. Parsons and E. Shils. Cambridge: Harvard University Press, 1959.

Koestlin, Julius. "Character." New.Schaff-Herzog Encyclopedia. 1958. Vol. 3.

Kohlberg, Lawrence. "Development of Moral Character and Moral Ideology." In Review of Child Development Research. Vol. 1, pp. 383-431. Edited by Martin L. Hoffman and Louis Wlad is Hoffman. New York: Russe11 Sage Foundation, 1964.

- "Moral Development and the Education of Adolescents."

In Adolescence, Readings in Behavior and Development, pp.

176-196. Edited by E11is Evans. Hinsdale, I11.: The Dryden Press, 1970.

- "Moral Education in the Schools: A Developmental View." The School Review 74 (Spring 1966): 1-30.

Krathwoh1, David R., Bloom, Benjamin S., and Masia, Bertram B. Taxonomy of Educational Objectives: The Classification of Educational Goals, Handbook II: Affective Domain. New York: David McKay, Inc., 1964.

Kreps, Carroll Ann. "College Students' Perceptions of Values Involved in Character Development." Thesis, Oklahoma State University, May 1970.

Lapsley, James N. "Character." Dictionary of Christian Ethics. 1967.

Lee, Dorothy. "Cu1ture and the Experience of Value." In New Knowledge in Human Values, pp. 165-177. Edited by Abraham J. Maslow. New York: Harper and Row Publishers, 1959.

Ligon, Ernest. Dimensions of Character. New York: Macmillan Co., 1956.

Manning, Frank E. "The Prophecy and the Law: Symbolism and Social Action in Seventh-day Adventism." Paper read at Adventist Workers' Meeting, Newfoundland, August 1973.

Martin, William E. "College Student Values: An Historical and Conceptual Perspective." Paper presented at American Personnel and Guidance Association, Atlantic City, N.J., 4-8 April 1971. Bethesda, Md.: ERIC Document Reproduction Service, ED 055 292, 1972 . 
McDouga11, W. An Introduction to Social Psychology. London: Methuen, 1908.

McGuire, Carson and White, George D. "The Measurement of Social Status." Report No. 3, Laboratory of Human Behavior, Department of Educational Psychology, University of Texas, 1955.

Mitche11, Claude. "Do Virtues and Vices Change?" School and Society 57 (January. 1943): 111, 112.

Moss, H. A. "Standards of Conduct for Students, Teachers, and Parents." Journal of Counseling Psychology, 1955, 2, 39-42.

Mouly, George J. Psychology for Effective Teaching. 2nd ed. Atlanta, Ga.: Holt, Rinehart \& Winston, 1968.

Mussen, Paul H. and Martin, William E. "Childhood and Preadolescence。" Encyclopedia of Educational Research. 1960.

Mussen, Paul H.; Conger, Janeway J.; Kagan, Jerome. Child Development and Personality. New York: Harper and Row, 1956.

Nye, F. Ivan. "Values, Family, and a Changing Society." Journal of Marriage and the Family 29 (May 1967): 241-248.

Oosterwal, Gottfried. Mission Possible. Nashville, Tenn.: Southern Publishing Association, 1972.

The Oxford Annotated.Bible, Revised Standard Version. Edited by Herbert G. May and Bruce M. Metzger. New York: Oxford University Press, 1962.

Parrilla, Lenoa. "A Comparative Study of Values Held by Black and White Children of the Lower Socio-economic Class." Major project, Andrews University, May 1971.

Peck, Robert and Havighurst, Robert. The Psychology of Character Development. New York: John Wiley, 1960.

Piaget, J. The Moral Judgment of the Child. New York: Harcourt, Brace and World, Inc., 1932.

Pressey, Sydney and Kuhlen, Raymond. Psychological Development Through the Life. New York: Harper Brothers, 1957.

Random House Dictionary of the English Language. 1966. S.v. "Perception."

Raths, Louise E.; Harmin, Merrill; and Simon, Sidney B. Values and Teaching. Columbus, Ohio: Charles E. Merrill Publishing Co., 1966. 
Rau, Lucy. "Conscience." In Identification and Child-rearing, pp. 199-240. Compiled by Sears, Robert R.; Rau, Lucy; and Alpert, Richard. Stanford, California: Stanford University Press, 1965.

Rothenberg, Michael G. "Character。" Encyclopedia Americana. 1973. Vol. 6.

Rowland, Monroe K. and DelCampo, Phillip. "The Values of the Educationally Disadvantaged: How Different are They?" Journal of Negro Education 37 (Winter, 1968): 86-89.

Salisbury, W. Seward. Religion in American Culture. Homewood, Illinois: The Dorsey Press, 1964.

Schuster, Jeanette $W$. "The Values of Negro and Caucasian Children: Do they Differ?" Journal of Negro Education 37 (Winter, 1968): $90-93$.

Schwartz, Gary. Sect Ideologies and Social Status. Chicago: University of Chicago Press, 1970.

"Seventh-day Adventist Youth at the Mid-Century." Review and Herald Publishing Association, Dept. of Education and Young People's Missionary Volunteer Dept. of the General Conference of Seventh-day Adventists. Washington, D.C. 1951.

Spence, Hartzell. The Story of America's Religions. New York: Holt, Rinehart and Winston, 1960.

Stinnett, Nick and Kreps, Carol A. "Values Relating to the Development of Character." Journal of Home Economics 64 (March 1972): 53-57.

Stone, Lawrence Joseph and Church, Joseph. Childhood and Adolescence. New York: Random House, 1957.

Sullivan, E. V.; McCullough, G.; and Stager, M. "A Developmental Study of the Relationship Between Conceptual, Ego, and Moral Development." Child Development 41 (1970): 399-411.

Theobald, Robin. "Seventh-day Adventists and the Millennium." In A Sociological Yearbook of Religion in Britain, pp. 111-131. Edited by Michael Hill. London: Student Christian Movement, 1974.

Thompson, George G. "Age Trends in Social Values During Adolescent Years." American Psychologist 4 (July 1949): 250. 1952.

- Child Psychology. Boston: Houghton Mifflin Company, 
Torke1son, G. M. "Using Learning Resources in Teaching Values." Social Studies Education 31 (January 1967): 41, 42.

Warner, W. L.; Meeker, M.; and Eells, K. Social Class in America. Chicago: Science Research Associates, 1949.

Weber, Max. "Part III: Religion." From Max Weber: Essays in Sociology. Edited and Translated by Hans H. Gerth and C. Wright Mil1s. New York: Oxford University Press, 1958.

White, Ellen G. Good Health. March, 1880 .

- Letter 14, 1885.

- The Great Controversy Between Christ and Satan During the Christian Dispensation. Mountain View, Calif.: Pacific Press, 1888.

- Patriarchs and Prophets or The Story of Patriarchs and Prophets as Illustrated in the Lives of Holy Men of 01d. Mountain View, Calif.: Pacific Press, 1890.

- Youths Instructor. January 5, 1893.

- Manuscript 13, $1894 a$.

- Manuscript 67, $1894 \mathrm{~b}$.

- Manuscript $130,1897 a$.

- Youths Instructor, January 28, $1897 \mathrm{~b}$.

- The Desire of Ages. Mountain View, Calif.: Pacific Press, 1898a.

- Letter $17,1898 \mathrm{~b}$.

- Review and Herald, May 10, 1898c.

- Christ's Object Lessons. Washington, D.C.: Review and Herald, 1900.

- Education. Mountain View, Calif.: Pacific Press, 1903a.

- Review and Herald. March 10, $1903 \mathrm{~b}$.

- Ministry of Healing. Mountain View, Calif.: Pacific Press, 1905.

- The Acts of the Apostles in the Proclamation of the Gospel of Jesus Christ. Mountain View, Calif.: Pacific Press, 1911. 
- The Story of Prophets and Kings as Illustrated in the Captivity and Restoration of Israel. Mountain View, Calif.: Pacific Press, 1917.

- Fundamentals of Christian Education. Nashville, Tenn.: Southern Publishing Association, 1923.

- Messages to Young People. Nashville, Tenn.: Southern Publishing Association, 1930.

- Counsels to Parents, Teachers, and Students. Mountain View, Calif.: Pacific Press, 1943.

- Testimonies for the Church. Vo1: 1:. Mountain View, Calif.: Pacific Press, 1948a.

- Testimonies for the Church. Vo1. 2. Mountain View, Calif.: Pacific Press, 1948b.

- Testimonies for the Chunch. Vol. 3. Mountain View, Calif.: Pacific Press, 1948c.

- Testimonies for the Church. Vo1. 4. Mountain View, Calif.: Pacific Press, 1948d.

- Testimonies for the Church. Vol. 6. Mountain View, Calif.: Pacific Press, 1948e.

- Testimonies for the Church. Vol. 7. Mountain View, Calif.: Pacific Press, $1948 \mathrm{f}$.

- The Adventist Home. Nashville, Tenn.: Southern

Publishing Association, 1952.

- Child Guidance. Nashville, Tenn.: Southern Publishing Association, 1954.

- The Sanctified Life. Washington, D.C.: Review and Herald, 1956.

- Selected Messages, Book 2. Washington, D.C.: Review and Herald, 1958.

- Our High Calling. Washington, D.C.: Review and Herald Publishing Association, 1961.

Wilson, Bryan. Religious Sects. New York: McGraw-Hill Book Company, 1970.

Wolfson, Bernice J. "Values and the Primary School Teacher." Social Studies Education 31 (January 1967): 37,38 . 
A P P E N I C E S 


\section{APPENDIX 1}

FORM LETTER FOR COMMUNITY STUDENTS

Garland Apt. B-21

Berrien Springs, MI 49103

April 1, 1974

Dear Student:

I am currently working on aMaster's Degree in Education with emphasis in Psychology here at Andrews University. I would like to solicit your cooperation in assisting me in a research study. Enclosed is a questionnaire. Please read the directions and check or fill in answers as appropriate to each question. Since your name is not required, please be as honest in your answers as possible.

The purpose of this study is to determine the perceptions of SDA college students concerning various aspects of character development. Your contribution will help educators to gain greater knowledge and insight into family relationships.

A pre-addressed envelope is enclosed for your convenience in mailing the completed questionnaire.

Thank you.

Sincerely yours,

(Ms.) Gertrude Jordan

$G J / j f c$

Enclosure 
FORM LETTER FOR DORMITORY STUDENTS

Garland Apt. B-21

Berrien Springs, MI 49103

April 1, 1974

\section{Dear Student:}

I am currently working on a Master's Degree in Education with emphasis in Psychology here at Andrews University. I would like to solicit your cooperation in assisting me in a research study. Enclosed is a questionnaire. Please read the directions and check or fill in answers as appropriate to each question. Since your name is not required, please be as honest in your answers as possible.

The purpose of this study is to determine the perceptions of SDA college students concerning various aspects of character development. Your contribution will help educators to gain greater knowledge and insight into family relationships.

Please deposit the completed questionnaire on or before April 3, 1974 in the special box at the receptionist desk of your dorm.

Thank you.

Sincerely yours,

(Ms.) Gertrude Jordan

$\mathrm{GJ} / \mathrm{jfc}$

Enclosure 


\section{APPENDIX 3}

\section{SAMPLE OF QUESTIONNAIRE}

Your cooperation in this research project is greatly appreciated. Your contribution in a research project of this type helps us to gain greater knowledge and insight into family relationships.

Please check or fill in answers as appropriate to each question. Since your name is not required, please be as honest in your answers as possible.

1. Sex: 1. male 2. female

2. Age: 1. 17-18 4. 23-24.

$$
\begin{aligned}
& 2 \cdot 19-20 \\
& \text { 3. } \\
& -\ldots 1-22
\end{aligned}
$$
5. 25 and over

3. College Classification:

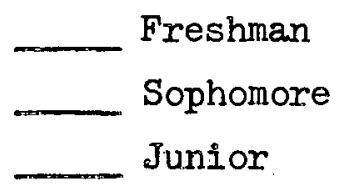
Senior Postgraduate Unclassified

4. College Major:

5. Nationality:

\begin{tabular}{ll} 
1. U.S. \\
2. \\
$\begin{array}{r}\text { 3. } \\
\text { 4. }\end{array}$ Oanadian \\
\hline
\end{tabular}

6. Race: 1. White 2. Black 3. Oriental 4. Other

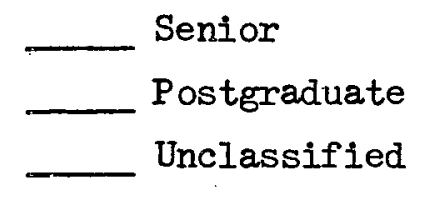


8. Religious preference:

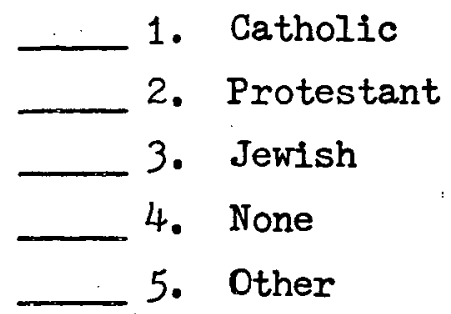

(Specjfy)

9. For the major part of your life have you lived:

1. On farm or in country

2. Small town under 25,000 population

3. City of 25,000 to 50,000 population

4. City of 50,000 to 100,000 population

5. City of over 1000,000 population

10. Do you have brothers or sisters?

1. Yes
2. No

11. If you have brothers or sisters, are you the

_ 1. Oldest child

2. Intermediate child

3. Youngest child

12. What is your marital status?

$\begin{array}{ll}\text { 1. Single } & \text { 4. Separated } \\ \text { 2. Married } & \text { 5. Widowed } \\ \text { 3. Divorced } & \end{array}$

13. What is your parents' marital status?

1. Living together

2. Separated or divorced (with no remarriage)

3. One of parents deceased (with no remarriage)

4. Divorced (with remarriage)

5. One of parents deceased (with remarriage)

14. Have you had a previous family relations course in high school or college?

1. Yes

2. No 
15.-16. What is the occupation of the head of your family of orientation household (teacher, minister, etc.

17. What is the primary source of the family income?

1. Inherited savings and investments

2. Earned wealth, transferable investment

3. Profits, royalties, fees

4. Salary, Commissions (regular, monthly, or yearly)

5. Hourly wages, weekly checks

6. Odd jobs, seasonal work, private charity

7. Public relief or charity

18. What is the highest educational attainment of the principal earner of the family income?

1. Completed graduate work for a profession

2. Graduated from a 4 year college

3. Attended college or university for two or more years

4. Graduated from high school

5. Attended high school, completed grade 9, but did not graduate

6. Completed grade 8 , but did not attend beyond grade 9

7. Less than grade 8

19. Circle the point on the scale which most nearly describes the type of discipline you had in your family.

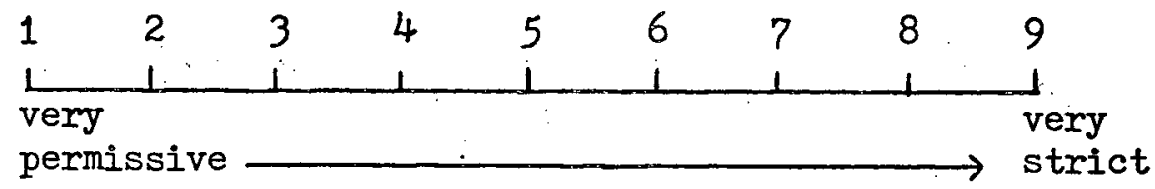

20. Which of the following indicates your relationship with your parents during childhood?

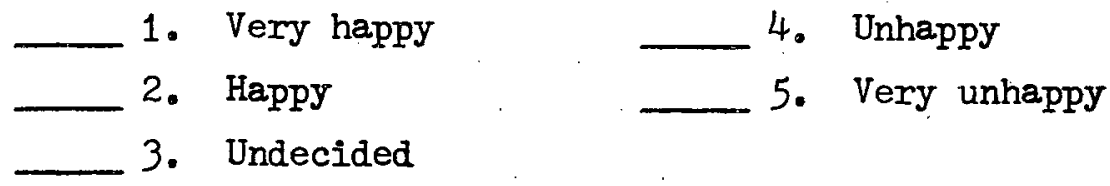

Character development is a great concern of all societies. Character is here defined as an individual's set of values which serve to guide his behavior. Following in the next question is a list of values which have often been considered to promote positive character development and also positive, fulfilling human living. We would like to know those which you feel are most important. 
21. - 22. From the following list of values which are often 23. - 24. considered to be involved in promoting positive 25. - 26. character development, please check the five (5) 27. - 28. values which you consider most important for parents 29. - 30. to assist their children in learning.

1. Determination and perserverance
2. Self-reliance
3. Seeing each person as having dignity
and worth (This involves respecting
rights and needs of others.)
4. Moral courage (courage to stand by
5. Spiritual development
6. Cooperation
7. Honesty and integrity
8. Ioyalty
9. Self-discipline
10. Feeling genuine concern and responsi-
11. Initiative
12. Intellectual inquisitiveness
13. Responsibility in performing tasks
14. Self-respect
15. Friendliness
16. Appreciation

31. -32 .

Which three (3) of the following values do you

33. -34 . think parents of today are most successful in

35. -36. helping their children learn?

1. Determination and perserverance

2. Self-reliance

3. Seeing each person as having dignity and worth (This involves respecting rights and needs of others.)

4. Moral courage (courage to stand by one's inner convictions)

5. Spiritual development

6. Cooperation

7. Honesty and integrity

8. Loyalty

9. Self-discipline

10. Feeling genuine concern and responsibility toward others

11. Initiative

12. Intellectual inquisitiveness

13. Responsibility in performing tasks

14. SeIf-respect

15. Friendliness

16. Appreciation 
37. - 38. Which three (3) of the following values do you 39. - 40. think parents of today most often fail to help 41. - 42. children learn?

1. Determination and perserverance
2. Self-reliance
3. Seeing each person as having dignity
and worth (this involves respecting
rights and needs of others.)
4. Moral courage (courage to stand by
5. Spiritual development
6. Cooperation
7. Honesty and integrity
8. Ioyalty
9. Self-discipline
10. Feeling genuine concern and responsi-
11. Initiative
12. Intellectual inquisitiveness
13. Responsibility in performing tasks
14. Self-respect
15. Friendiness
16. Appreciation

43. Which parent do you feel is more important in influencing the character development of the child?

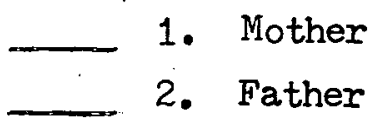

44. Which one of the following is most influential in affecting the character development of children?

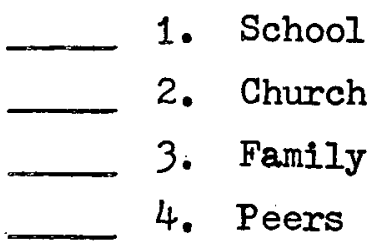

45. In which one of the following ways do you think values involved in character development are most effectively learned?

1. Rewarded for desirable behavior and punished for undesirable behavior.

2. Following examples and models of behavior of others

3. Realizing consequences of various types of behavior

4. Other (Specify) 
46. Which one of the following ways do you think parents most of ten use in helping children learn values involved in positive character development?

1. Rewarding desirable behavior and punishing undesirable behavior

2. Providing positive examples and model of behavior of other

3. Helping child to realize consequence of various types of behavior

4. Other (Specify) 


\section{APPENDIX 4}

\section{MCGUIRE-WHITE SOCIAL CLASS INDEX}

The McGuire-White Index of Socio-economic Status is divided into three areas--occupation of family head, source of the family income, and education of the family head. The first rating, the rating of occupation, is presented in Table 40. If the respondent reports the family head is president of a corporation, the occupation is given a rating of " 1 "; if the respondent reports the family head to be a high school teacher, the occupation is given a rating of " 2 "; if the respondent reports the family head to be a truck driver, the occupation is given a rating of " 6 ", etc.

Whatever the respondent checks as being the primary source of income is simply recorded as that number. For example, if the respondent checks profits and royalties on the questionniare, the score of " 3 " is recorded.

The same is true for education. If the respondent indicates the family head completed graduate work, a score of "1" is recorded.

To calculate the total socio-economic score for each subject, the rating for occupation is multiplied by 5; the rating for source of income is multiplied by 4; the rating for education is multiplied by 3--then the three scores are added together for total score. The total score is checked against the listed five categories to see which level the respondent is in. For example, if the total score is 15, it would fall in the Upper class category and the respondent would receive a socio-economic code of " 1 ". 
TABLE 40

MCGUIRE-WHITE SOCIAL CLASS INDEX--OCCUPATIONS*

\begin{tabular}{|c|c|c|c|c|c|c|c|}
\hline Rate & Professionals & Proprietors & Businessmen & White collar & Blue Collar & Service & Farm People \\
\hline 1. & $\begin{array}{l}\text { Lawyer, Judge } \\
\text { physician, eng- } \\
\text { ineer, professor } \\
\text { school supt. } \\
\text { et al }\end{array}$ & $\begin{array}{l}\text { Large busines- } \\
\text { ses valued at } \\
\$ 100,000 \text { or } \\
\text { more depending } \\
\text { on community }\end{array}$ & $\begin{array}{l}\text { Top executives, } \\
\text { President, et al } \\
\text { of corporation, } \\
\text { bank, public } \\
\text { utility }\end{array}$ & $\begin{array}{l}\text { CPS; editor } \\
\text { of newspaper, } \\
\text { magazine; } \\
\text { exec. sec. of } \\
\text { status organ. }\end{array}$ & & & $\begin{array}{l}\text { Gentlemen farmer or } \\
\text { landowner who do not } \\
\text { supervise directly } \\
\text { their property. }\end{array}$ \\
\hline 2. & $\begin{array}{l}\text { High school } \\
\text { teacher, libra- } \\
\text { rlan, and others } \\
\text { with 4-year } \\
\text { degree }\end{array}$ & $\begin{array}{l}\text { Business value } \\
\text { at } \$ 50,000 \text { to } \\
\$ 100,000\end{array}$ & $\begin{array}{l}\text { Asst. office } \\
\text { dept. mgrs. or } \\
\text { supervisors, } \\
\text { some manufac- } \\
\text { turing agents }\end{array}$ & $\begin{array}{l}\text { Accountant; } \\
\text { insurance, real } \\
\text { estate, stock } \\
\text { salesmen; } \\
\text { edit. writer }\end{array}$ & & & $\begin{array}{l}\text { Land operators who } \\
\text { supervise properties } \\
\text { \& have an active urben } \\
\text { life. }\end{array}$ \\
\hline 3. & $\begin{array}{l}\text { Grade school } \\
\text { teacher, regis- } \\
\text { tered nurse, } \\
\text { minister with- } \\
\text { out } 4-y r \text { degree }\end{array}$ & $\begin{array}{l}\text { Business or } \\
\text { equity value } \\
\text { from } \$ 10,000 \\
\text { to } \$ 50,000\end{array}$ & $\begin{array}{l}\text { Manager of } \\
\text { small branches } \\
\text { or buyers \& } \\
\text { salesmen of } \\
\text { known mchdse. }\end{array}$ & $\begin{array}{l}\text { Bank clerk, } \\
\text { auto salesman } \\
\text { postal clerk, } \\
\text { RR or tel. } \\
\text { agt. or supv. }\end{array}$ & $\begin{array}{l}\text { Small contr. } \\
\text { who works } \\
\text { at or super- } \\
\text { vises his job }\end{array}$ & T & $\begin{array}{l}\text { Farm owners with "hired } \\
\text { help;" operators of } \\
\text { leased property who } \\
\text { supervises }\end{array}$ \\
\hline 4. & & $\begin{array}{l}\text { Business or } \\
\text { equity value } \\
\text { from } \$ 5,000 \\
\text { to } \$ 10,000\end{array}$ & $\begin{array}{l}\text { (Stenographer, bc } \\
\text { t1cket agent, sal } \\
\text { in dept stores, }\end{array}$ & $\begin{array}{l}\text { keeper; } \\
\text { people }\end{array}$ & $\begin{array}{l}\text { Foreman; mstr } \\
\text { carpenter, elec- } \\
\text { trician, et al } \\
\text { RR engineer }\end{array}$ & $\begin{array}{l}\text { Police } \\
\text { Captain, } \\
\text { tailor, RR } \\
\text { conduct. } \\
\text { watchmaker } \\
\end{array}$ & $\begin{array}{l}\text { Small landowner, operator } \\
\text { of rented property } \\
\text { hiring "hands" }\end{array}$ \\
\hline$\overline{50}$ & & $\begin{array}{l}\text { Business or } \\
\text { equity value } \\
\text { from } \$ 2,000 \\
\text { to } \$ 5,000 \\
\end{array}$ & $\begin{array}{l}\text { (Dime store clerk } \\
\text { clerks; telephone } \\
\text { operators, et al. }\end{array}$ & $\begin{array}{l}\text { grocery } \\
\text { beauty }\end{array}$ & $\begin{array}{l}\text { Apprentice to } \\
\text { skilled trades } \\
\text { repairmen: med. } \\
\text { skilled wrks. }\end{array}$ & $\begin{array}{l}\text { Policeman } \\
\text { barber, prac. } \\
\text { nurse, brake- } \\
\text { men, et al. }\end{array}$ & $\begin{array}{l}\text { Tenants on good farms } \\
\text { foreman; owners of } \\
\text { farms who "hire out" }\end{array}$ \\
\hline 6 & . & $\begin{array}{l}\text { Business or } \\
\text { equity value } \\
\text { at less than } \\
\$ 2,000\end{array}$ & & \multicolumn{2}{|c|}{$\begin{array}{l}\text { Semi-skilled factory and } \\
\text { production workers; assis- } \\
\text { tants to skilled trade; } \\
\text { warehousemen, watchmen }\end{array}$} & $\begin{array}{l}\text { Taxi \& trk } \\
\text { dxivers; } \\
\text { waiter, } \\
\text { waitress, } \\
\text { gas stn. ar. }\end{array}$ & $\begin{array}{l}\text { Sharecroppers' estab- } \\
\text { lished farm laborers. } \\
\text { subs'ce farmers. }\end{array}$ \\
\hline 7. & \multicolumn{2}{|c|}{ "Reputed Lawbreakers" } & & \multicolumn{2}{|c|}{$\begin{array}{l}\text { Heavy labor, odd-job meny } \\
\text { mine or mill hands, un- } \\
\text { skilled workers }\end{array}$} & $\begin{array}{l}\text { Domestic } \\
\text { help, bus } \\
\text { boy, scrub } \\
\text { women, jani- } \\
\text { tor helper }\end{array}$ & $\begin{array}{l}\text { Migrant workers } \\
\text { "squatters-nesters" }\end{array}$ \\
\hline
\end{tabular}

* For an original table, consult Warner's revised scale (12, pp. 140-141). Modifications in the present table represent revisions made after interviewing in communties and are types to guide other ratings. 